\title{
Alkali-activated materials obtained from asphalt fillers and fluorescent lamps urban and industrial-wastes
}

M. Vicent ${ }^{\text {a }}$, M. Criado ${ }^{\text {b,c* }}$, J. García-Ten $^{\text {a }}$

5

6 a Instituto de Tecnología Cerámica (ITC), Asociación de Investigación de las Industrias 7 Cerámicas (AICE), Campus Universitario Riu Sec (UJI), Avda. de Vicent Sos Baynat s/n, 812006 Castellón, Spain

$9{ }^{\mathrm{b}}$ Department of Materials Science and Engineering, The University of Sheffield, Sir Robert 10 Hadfield Building, Sheffield S1 3JD, UK

$11{ }^{\mathrm{c}}$ Department of Construction, Instituto de Ciencias de la Construcción Eduardo Torroja-CSIC, $12 \mathrm{c} /$ Serrano Galvache 4, 28033 Madrid, Spain

13 *corresponding author: maria.criado@ietcc.csic.es meriadosanz@gmail.com, phone +34 91 $14 \quad 3020440$, fax +34913020700

15

16

Abstract

Alkali-activated materials, which some authors often call geopolymers, can be described as inorganic solids that form three-dimensional networks with molecular structure similar to organic polymers, and are able to combine qualities similar to cements with those of traditional ceramics and zeolites.

The polymerisation reaction takes place between solid aluminosilicate powders and alkaline solutions at low temperature and therefore this process is classified as eco-efficient. In addition, this process allows the recycling of a large variety of amorphous aluminosilicate waste materials, which makes it very attractive from the environmental point of view.

In this work, alkaline activated materials have been prepared using exclusively industrial and urban wastes to replace both, the aluminosilicate powder (from asphalt fillers and fluorescent lamps wastes) and the alkaline activator (from aluminium manufacturing industry). The materials obtained have been fully characterised. A mineralogical and microstructural study of these materials was conducted by FTIR, XRD, and ESEM-EDX. Moreover, it has been 
30 determined their bulk density, strength resistance, water absorption and leaching tests, 31 confirming their suitability for being used as urban pavement.

32 Keywords: alkali-activated materials; industrial and urban wastes; urban pavement. 


\section{Introduction}

In recent years, the European Commission (EC) has launched a series of initiatives to promote the transition from the current linear economy model (to make - to use - to throw away, implemented in most activities) to a circular model, whose main objectives are: to optimise the use of resources and to avoid and / or to minimise the generation of waste, that is to reduce the generation of industrial waste. In addition to that, the objectives and targets set in European legislation have been key drivers to improve waste management, stimulate innovation in recycling, limit the use of landfilling, and create incentives to change consumer behaviour. If the waste materials are re-manufactured, reused and recycled, and if one industry's waste becomes another's raw material, it will be possible to move to a more circular economy where waste materials are eliminated and resources are used in an efficient and sustainable way (COM (2015) 614 final, 2015; COM (2017) 33 final, 2017).

Alkaline activation is a process in which an aluminosilicate powder is mixed with an alkaline activator to give rise to a mass with the ability to set and harden in a short period of time. As a product of the reaction, a compact material with cementing properties and high mechanical strength is obtained. Alkali-activated materials are formed as a consequence of the polymerisation of simple tetrahedral silicon and aluminium units. The chemical process for the formation of the alkali-activated low calcium materials such as fly ash and metakaolin consists of a first stage of dissolution of the raw materials in the alkaline solution to form inorganic monomers, and a second stage of polycondensation of these monomers to form polymeric structures of oxides in three-dimensional networks (Buchwald et al., 2009). Both steps occur at room temperature or at temperatures below $200{ }^{\circ} \mathrm{C}$, so alkaline activation is considered an eco-efficient or sustainable process.

It is important to note that in the alkaline activation process the thermal stage is eliminated with respect to concrete or ceramic materials manufacturing, resulting in a significant carbon dioxide emissions reduction. Nowadays, in the traditional process, it is necessary to treat the raw materials at $1400-1500{ }^{\circ} \mathrm{C}$ in order to obtain the clinker, which is essential in most of the cements and therefore in concretes. On their behalf, ceramic tiles are produced at 1100-1200 ${ }^{\circ} \mathrm{C}$. On the contrary, the alkali activation process requires low temperatures $\left(\mathrm{T}<200{ }^{\circ} \mathrm{C}\right)$, offering considerable energy savings compared to the traditional process of manufacturing urban pavements. Moreover, during the thermal stage, all volatile compounds from the raw materials evolve what make difficult the recycling of some types of waste. Thus, by eliminating 
the thermal stage, not only emissions of carbon dioxide will be reduced, but also emissions of sulphur, fluorine, chlorine and heavy metals compounds. This makes alkaline activation an attractive technology from an environmental point of view.

There is a large quantity of literature about the use of waste to replace aluminosilicate raw materials in the alkaline activation process. Much of the work reported in the literature has been based on the study of fly ashes from thermoelectric power plants (Criado et al., 2012; Fernández-Jiménez et al., 2008; Görhan and Kürklü, 2014; Palomo et al., 1999). This kind of fly ash particles is generally spherical in shape, though it is not necessarily homogeneous, so that the fly ash is constituted by a major vitreous phase and by some minor crystalline phases such as quartz, mullite, hematite, magnetite and some $\mathrm{CaO}$ and $\mathrm{TiO}_{2}$ (Fernández-Jiménez and Palomo, 2003; Ryu et al., 2013; Soutsos et al., 2016). The chemical composition of fly ash is silicon-silica, aluminium-alumina, and iron oxides. The amount of crystalline and glassy phase depends largely on the combustion and gasification process used at each power plant. When the maximum temperature of the combustion process is above $1200{ }^{\circ} \mathrm{C}$ and the cooling time is short, the ash produced is mostly glassy phase material. Alkali-activated materials prepared by fly ashes exhibit good strength values; the activation of fly ash leads to the formation of alkaline aluminosilicate hydrate gel, main reaction product, which is the main responsible for the mechanical properties in the resulting material (Fernández-Jiménez et al., 2008).

To a lesser extent, there is also literature about the use of fly ash and bottom ash from the incineration of municipal urban solid waste (MSW) (Lancellotti et al., 2010; Zheng et al., 2011). Ashes from biomass (Shearer et al., 2016) have also been studied, as well as other amorphous residues containing silicon and aluminium in their structure (Frías et al., 2012; Hwang and Huynh, 2015; Mijarsh et al., 2015; Santa et al., 2013; Tchadjié et al., 2016; Tchakoute et al., 2013).

In addition, there are very few studies on the use of waste materials for replacing alkaline activators. Alkaline solutions able to interact with aluminosilicates include: alkaline or alkaline-earth hydroxides ( $\left.\mathrm{ROH}, \mathrm{R}(\mathrm{OH})_{2}\right)$, weak acid salts $\left(\mathrm{R}_{2} \mathrm{CO}_{3}, \mathrm{R}_{2} \mathrm{~S}, \mathrm{RF}\right)$, strong acid salts $\left(\mathrm{Na}_{2} \mathrm{SO}_{4}, \mathrm{CaSO}_{4} \cdot 2 \mathrm{H}_{2} \mathrm{O}\right)$ and $\mathrm{R}_{2} \mathrm{O}(\mathrm{n}) \mathrm{SiO}_{2}$-type siliceous salts, where $\mathrm{R}$ is an alkaline ion such as $\mathrm{Na}, \mathrm{K}$ or Li. From the standpoint of end-product strength and other properties, the most effective of these activators are a mixture of sodium hydroxide and sodium silicate hydrate (waterglass). Glass waste and rice husk ash have been successful demonstrated to be a viable 
97 substitute for the waterglass (Tchakouté et al., 2016; Torres-Carrasco and Puertas, 2015); 98 however, there are no studies about the substitution of sodium hydroxide by a waste material.

99 In this work, alkali-activated materials have been prepared using exclusively waste materials; 100 neither primary raw materials nor commercial activators have been used. In this way, asphalt 101 fillers and fluorescent lamps waste, that are currently landfilled, have been used as 102 aluminosilicate waste materials. In addition, sodium hydroxide solutions obtained from the 103 aluminium manufacturing industry has been used as alkaline activator.

104 The starting materials were previously characterised by chemical and mineralogy methods. A 105 deep and detail mineralogical and microstructural characterisation of the different alkali106 activated materials were also carried out by infrared spectroscopy (FTIR), X-ray diffractometry 107 (XRD), and environmental scanning electron microscopy (ESEM). Moreover, compacity, 108 mechanical strength, water absorption and leaching tests were carried out to confirm their 109 suitability for their use as urban pavement. 
2.1. Waste materials characterisation

To produce the alkali-activated materials, asphalt fillers waste (A) and fluorescence lamp waste (FL), were used as starting materials. Asphalt fillers, which are an industrial waste, came from the elimination of the fines of the calcareous aggregates used in road paving. Fluorescence lamps, which are an urban waste, were provided by a Spanish waste manager. Both waste materials were milled and sieved to obtain a pulverulent material with a particle size $<100 \mu \mathrm{m}$ (Figure 1). For this, $100 \mathrm{~g}$ of waste material with a solid content of $70 \%$ were wet grounded in a an alumina planetary alumina ball mill (MILL-2, Gabbrielli, srl, Italy) with distilled water for 25 minutes at $410 \mathrm{rpm}$. After that, the material was dried in infrared lamps and the dry powder was de-agglomerated in a centrifugal laboratory crusher (Model 10000, Orto Alresa, Spain).

The particle size distribution of the obtained powders was determined by laser diffraction (Mastersizer 2000, Malvern Instruments Ltd, UK) and the chemical composition by wavelength dispersive X-ray fluorescence (Axios, PANalytical, The Netherlands).

Figure 1. Images of (a) original asphalt waste, (b) powder asphalt waste, (c) cut glass of fluorescent lamp waste and (d) powder fluorescent lamp waste.

The activating agent were sodium hydroxide solutions obtained from the cleaning of the moulds used for extruding aluminium parts provided by a Spanish aluminium manufacturing industry.

\subsection{Preparation of test specimens}

Compositions detailed in table 1 were activated using 8.8M NaOH waste solution with different liquid/solid ratio (1/s), being 0.45 for $100 \mathrm{~A}, 0.6$ for $100 \mathrm{FL}$ and 0.5 for the other mixtures (87.5A-12.5FL, 75A-25FL and 62.5A-37.5FL). The change in the $1 / \mathrm{s}$ ratio was conducted to reach a suitable paste viscosity for filling the moulds during shaping.

Compositions were mixed with the alkaline solution for 10 minutes in a mixer with a blade and a bucket speed of 360 and $60 \mathrm{rpm}$, respectively. 
Table 1 . Compositions studied (\% by weight).

In addition, 75A-25FL mixture was also activated with 9.9M NaOH waste (75A-25FL-2). This new test was carried out to know the effect of a higher concentration of $\mathrm{NaOH}$ and dissolved aluminium in the alkaline solution on the mineralogical, microstructural and mechanical performance of the alkali-activated material.

The obtained pastes were shaped in $80 \times 20 \times 7 \mathrm{~mm}$ moulds and subsequently cured in an oven at $85{ }^{\circ} \mathrm{C}$ in a saturated water vapour atmosphere for 20 hours. After that, the specimens were demoulded and dried at room temperature for 24 hours before determining their properties.

\subsection{Characterisation of the test specimens}

The mineralogical and microstructural characterisation were carried out through the following techniques:

- X-ray diffraction, XRD (D2 Phaser, Bruker, Germany), with $\mathrm{Cu}-\mathrm{K} \alpha$ radiation and a nickel filter. The tests were conducted with a step size of $0.02^{\circ}$ and a counting time of $1.1 \mathrm{~s} / \mathrm{step}$, from $5^{\circ}$ to $60^{\circ} 2 \theta$.

- Fourier-transform infrared spectroscopy, FTIR (Model 1600, Perkin Elmer Inc., Belgium). The samples were prepared by mixing $200 \mathrm{mg}$ of $\mathrm{KBr}$ and $1 \mathrm{mg}$ of the powered sample. Spectral analysis was performed over the range $4000-400 \mathrm{~cm}^{-1}$ at a resolution of $4 \mathrm{~cm}^{-1}(16$ scans).

- Environmental scanning electron microscopy, ESEM (TM3030, Hitachi Ltd., Japan) and energy dispersive X-ray microanalysis, EDX (Quantax 70, Bruker, Germany). The acceleration voltage used was $15 \mathrm{kV}$ and for elemental analysis a total of 25 acquisitions were obtained per sample.

The ability of the alkali-activated materials for being used as urban pavement was determined by:

- Bulk density, determined by the mercury immersion method.

- Three point bending strength. Tests were conducted in a mechanical testing machine (CM-C, Hoytom, S.L., Spain) at a constant deformation speed of $5 \mathrm{~mm} / \mathrm{min}$. 
by the specimens after being subjected to a vacuum pressure of $91 \mathrm{kPa}$ for 30 minutes. After

that, they were immersed in water and remained in water at atmospheric pressure for 15

\section{minutes.}

-Leaching tests. There are no regulations on leachate in building materials; that is the reason why they have been followed the criteria and procedures for the acceptance of waste at landfills. Leaching tests were carried out following the procedure described in the standard UNE-EN 12457-2 (UNE-EN 12457-2:2003, 2003). For this $0.045 \pm 0.005 \mathrm{~kg}$ of sample was stirred in distilled water with a liquid/solid ratio of $101 / \mathrm{kg}$. The sample was under stirring for 24 hours and after that, it was filtered. Analysis of elements in the leachate was performed by inductively coupled plasma optical emission spectrometry, ICP-OES (Model 5100, Agilent Technologies, USA), flame atomic absorption spectrophotometry, FAAS (Aanalyst 400, Perkin Elmer Inc., USA) and ionic chromatography, IC (ICS1000, Dionex, USA).

\section{Results and discussion}

\subsection{Waste materials characterisation}

The particle size distribution of the ground powders is shown in figure 2. FL particle size is slightly smaller than the one corresponding to A powder, being the average size value $6.8 \mu \mathrm{m}$ and $11.3 \mu \mathrm{m}$, respectively. It should be notice that FL shows a monomodal particle-size distribution while A particle size is bimodal with two maximum peaks at 2.5 and $28.3 \mu \mathrm{m}$.

The chemical composition of the powdered waste materials is shown in table 2. Asphalt filler waste was formed mainly by $\mathrm{CaO}$ and $\mathrm{MgO}$, coming from carbonates, and heavy metals were not detected. Fluorescence lamp waste came from the cleaning treatment of fluorescence lamps, in which rare earth elements were removed. The waste contained a large amount of $\mathrm{SiO}_{2}$ and was still contaminated with heavy metals (Table 2), plastic and other elements such as adhesives and resins.

Figure 2. Particle size distributions of A and FL milled powders.

Table 2. Chemical composition of asphalt filler (A) and fluorescence lamp (FL) waste powders, and $\mathrm{NaOH}$ waste solution dried at $110^{\circ} \mathrm{C}$, determined by WD-XRF (\% by weight). 
Table 3 shows the molarities of the different samples of the sodium hydroxide waste which change according to the time that they had been stored in the industry. The molarities increased with the storage time due to the evaporation of the water contained in the tanks. Apart from sodium, $\mathrm{NaOH}$ waste solutions contained impurities of aluminium, as it is shown in the chemical analysis (Table 2).

Table 3. Molarity of $\mathrm{NaOH}$ waste samples with different the storage times.

\subsection{Mineralogical and microstructural characterisation}

\subsubsection{X-ray diffraction (XRD)}

Figure 3(a) shows the XRD pattern of both raw materials. FL waste consisted of an amorphous phase, according to the wide and diffusive reflection in the interval of $15-35^{\circ}$ angles $2 \theta$. XRD analysis of A waste revealed quite different crystalline phases such as calcite $\left(\mathrm{CaCO}_{3}\right)$ (PDF \# 86-2334), dolomite $\left(\mathrm{CaMg}\left(\mathrm{CO}_{3}\right)_{2}\right)$ (PDF \# 11-0078), muscovite $\left(\mathrm{KAl}_{2}\left(\mathrm{Si}_{3} \mathrm{AlO}_{10}\right)(\mathrm{OH})_{2}\right)(\mathrm{PDF}$ \# 01-1098) and quartz ( $\left.\mathrm{SiO}_{2}\right)$ (PDF \# 85-0865). These crystalline phases are the typical ones used as raw materials in the production of the asphalt (Jelić et al., 2018).

Figure 3. XRD patterns of (a) the starting materials and (b) the activated materials.

In the alkali-activated pure materials (100FL and 100A), XRD patterns showed differences in the identified phases with respect to the anhydrous raw materials. In 100FL, the halo attributed to the amorphous phase in the initial fluorescence lamp waste shifted to slightly higher angular values $\left(2 \theta=21-38^{\circ}\right)$, indicating the formation of a calcium silicate hydrated $(\mathrm{C}-\mathrm{S}-\mathrm{H})$ with $\mathrm{Na}$ in its structure. In 100A, phases identified were pirssonite $\left(\mathrm{Na}_{2} \mathrm{Ca}\left(\mathrm{CO}_{3}\right)_{2} .2 \mathrm{H}_{2} \mathrm{O}\right)$ (PDF \# 241065), hydrotalcite $\left(\left(\mathrm{Mg}_{0.667} \mathrm{Al}_{0.33}\right)(\mathrm{OH})_{2}\left(\mathrm{CO}_{3}\right)_{0.137}\left(\mathrm{H}_{2} \mathrm{O}\right)_{0.5}\right)$ (PDF \# 89-0460) and brucite $\left(\mathrm{Mg}(\mathrm{OH})_{2}\right)$. The crystalline phases (calcite, quartz, muscovite and dolomite) were also detected, while that the three formers remained unaltered with the activation, the amount of dolomite decreased.

XRD patterns for the mixtures (87.5A-12.5FL, 75A-25FL and 62.5A-37.5FL) are shown in figure 3(b). Limited amorphicity was observed and the new crystalline phases detected were the same that those formed in 100A next to thermonatrite $\left(\mathrm{Na}_{2} \mathrm{CO}_{3} \cdot \mathrm{H}_{2} \mathrm{O}\right)(\mathrm{PDF} \#$ 08-0448). The formation of single and double sodium carbonate was favoured due to the atmospheric 
carbonation, $\mathrm{CO}_{2}$ reacts with $\mathrm{Na}$ ions supplied by the alkaline solution (Komnitsas et al., 2015). In addition, the amount of thermonatrite $\left(\mathrm{Na}_{2} \mathrm{CO}_{3} \cdot \mathrm{H}_{2} \mathrm{O}\right)$ increased with the presence of a large percentage of FL in the samples, to the detriment of pirssonite $\left(\mathrm{Na}_{2} \mathrm{Ca}\left(\mathrm{CO}_{3}\right)_{2} \cdot 2 \mathrm{H}_{2} \mathrm{O}\right)$ and brucite $\left(\mathrm{Mg}(\mathrm{OH})_{2}\right)$. Fluorescence lamp waste presented a higher amount of $\mathrm{Na}_{2} \mathrm{O}$ in its chemical composition than asphalt fillers waste and the formation of single sodium carbonate was favoured.

In 75A-25FL sample activated with richer-A1 NaOH solution (75A-25FL-2), the diffractogram presented clear differences with respect to its analogue, new phases were identified such as an unnamed zeolite $\left(\mathrm{Na}_{8} \mathrm{Al}_{6} \mathrm{Si}_{6} \mathrm{O}_{24}\left(\mathrm{CO}_{3}\right)_{0.5}(\mathrm{OH}) .3 \mathrm{H}_{2} \mathrm{O}\right)$ ( $\mathrm{PDF} \#$ 49-0757) and hydrogrossularite katoite $\left(\mathrm{Ca}_{3} \mathrm{Al}_{2}\left(\mathrm{SiO}_{4}\right)_{1.5}(\mathrm{OH})_{6} \mathrm{Ca}_{3} \mathrm{Al}_{2}(\mathrm{OH})_{12}\right.$, ealcium aluminium garnet) (PDF \# 38-368 02 1124), while that pirssonite and brucite were not formed. Therefore, it was clearly observed that the presence of a higher amount of aluminium promoted the formation of aluminium compounds. In this mixture, the amount of dolomite was higher than calcite.

\subsubsection{Fourier-transform infrared spectroscopy (FTIR)}

244 Figure 4(a) shows the infrared spectroscopic results for the fluorescence lamp waste and asphalt 245 fillers waste. The respective spectra band assignments are summarised in table 4. In 246 fluorescence lamp waste spectrum, the bands detected in the region of $3450 \mathrm{~cm}^{-1}$ (peak 4) and around $1650 \mathrm{~cm}^{-1}$ (peak 17) were assigned to stretching and bending $\mathrm{H}-\mathrm{O}-\mathrm{H}$ vibration of water molecules. The peaks around 2920 and $2850 \mathrm{~cm}^{-1}$ (peaks 9,10) were typical C-H stretching vibrations in aliphatic chains of plastic, adhesives or resins (Silverstein et al., 2014). The small band at $1430 \mathrm{~cm}^{-1}$ (peak 18) was attributed to asymmetric stretching vibration of $\mathrm{CO}_{3}{ }^{2-}$ groups. Two main very wide and intense bands characteristics of the internal vibrations in $\mathrm{TO}_{4}$ tetrahedra $\left(\mathrm{T}=\mathrm{Si}\right.$ or $\mathrm{Al}$ ) were observed. The band at $1040 \mathrm{~cm}^{-1}$ (peak 21) was associated with T-O bond asymmetric stretching vibration, $v_{3}(\mathrm{Si}-\mathrm{O})$, of the amorphous phase of the fluorescence lamp waste, and the band at $472 \mathrm{~cm}^{-1}$ (peak 34), corresponded to T-O bond internal deformation or bending vibration, $v_{4}$ (O-Si-O) (Gadsden, 1975). The band at $775 \mathrm{~cm}^{-1}$ (peak 25) was attributed to vibrations of $\mathrm{AlO}_{4}{ }^{-}$tetrahedral groups (Gadsden, 1975).

Figure 4. FTIR spectra of (a) the starting materials and (b) the activated materials.

Table 4. Bands on the FTIR spectra of the starting materials and the activated materials. 
The FTIR spectrum of asphalt fillers waste showed a small peak at $3697 \mathrm{~cm}^{-1}$ (peak 1) due to hydroxyl stretching vibration in brucite (Frost and Kloprogge, 1999). The bands at 3621, 3431, 1028, 534 and $475 \mathrm{~cm}^{-1}$ (peaks 3, 5, 22, 32 and 33) were assigned to muscovite (Vaculikova and Plevova, 2005). The bands at 2973, 2957, 2876, 2513, 1799, 1433, 875, 728 and $712 \mathrm{~cm}^{-1}$ (peaks $11,12,13,14,15,18,23,27$ and 28 ) were attributed to the modes of $\mathrm{CO}_{3}{ }^{2-}$ in $\mathrm{CaCO}_{3}$ (Vaculikova and Plevova, 2005). The infrared spectra of calcite and dolomite were practically identical due to the similarity of the atomic structure of these minerals.

Figure 4(b) shows the infrared spectra of all activated samples. Table 4 lists the band attribution for all the spectra shown in this figure. In 100FL spectrum, a series of new bands were observed at $2966,1728,1274$ and $755 \mathrm{~cm}^{-1}$, all of them belonged to vibration bands of organic compounds. The triplet of signals $\left(2966,2919,2851 \mathrm{~cm}^{-1}\right.$, peaks 8,9 and 10) were ascribed to asymmetric stretching of $\mathrm{CH}_{3}$ groups, asymmetric stretching of $\mathrm{CH}_{2}$ groups and symmetric stretching of $\mathrm{CH}_{3}$ groups (Silverstein et al., 2014), the peak at $1728 \mathrm{~cm}^{-1}$ (peak 16) was assigned to the asymmetric stretching of $\mathrm{C}=\mathrm{O}$ bond (Silverstein et al., 2014). The bands at 1274 and 755 $\mathrm{cm}^{-1}$ (peak 19 and 26) were assigned to bending vibrations of Si-C bonds (Silverstein et al., 2014). The bands at 1462 and $867 \mathrm{~cm}^{-1}$ (peak 18 and 23) were due to atmospheric carbonation and were attributed to asymmetric stretching vibrations and out-of-plane deformation, respectively, of $\mathrm{CO}_{3}{ }^{2-}$ groups. In the activated fluorescence lamp waste, the position of the main band of T-O bond asymmetric stretching was shifted to lower wavenumbers $\left(1002 \mathrm{~cm}^{-1}\right.$, peak 21), confirming the formation of the calcium silicate hydrated gel (Hajimohammadi et al., 2011). The appearance of band at lower wavenumbers was due to the formation of Si-O-T bonds with an increase in the length and/or angle. In addition, this spectrum showed other peaks at around $634 \mathrm{~cm}^{-1}$ (Si-O-Si bending vibration, peak 30$)$ and $456 \mathrm{~cm}^{-1}(0-\mathrm{Si}-\mathrm{O}$ vibrations, peak 34), likewise typical of C-S-H gels (García-Lodeiro et al., 2008).

In 100A spectrum, the peaks associated to muscovite and calcite/dolomite compounds were still observed and the intensity of the peak at $3697 \mathrm{~cm}^{-1}$ (peak 1) was increased, indicating the formation of a higher amount of brucite, also observed through XRD. Moreover, new set of peaks were detected at 3227, 3075, 1069 and $655 \mathrm{~cm}^{-1}$ (peaks 6, 7, 20 and 29), they were assigned to the presence of pirssonite (Frost and Dickfos, 2007). This compound has other bands at 875 and $712 \mathrm{~cm}^{-1}$ (peaks 23 and 28), which overlapped with the vibrations bands of $\mathrm{CO}_{3}{ }^{2-}$ groups of calcite (Frost and Dickfos, 2007). The asymmetric stretching band of $\mathrm{CO}_{3}{ }^{2-}$ group (peak 18) presented two small peaks, indicating there was a mixture of carbonate compounds in the sample, such as pirssonite, calcite and dolomite. 
The $87.5 \mathrm{~A}-12.5 \mathrm{FL}, 75 \mathrm{~A}-25 \mathrm{FL}$ and $62.5 \mathrm{~A}-37.5 \mathrm{FL}$ spectra showed the two main bands characteristics of the internal vibrations in $\mathrm{TO}_{4}$ tetrahedra $(\mathrm{T}=\mathrm{Si}$ or $\mathrm{Al})$ of the calcium silicate hydrated gel. The first band (peak 21) appeared at $1017 \mathrm{~cm}^{-1}$ for $87.5 \mathrm{~A}-12.5 \mathrm{FL}, 75 \mathrm{~A}-25 \mathrm{FL}$ mixtures and at $1002 \mathrm{~cm}^{-1}$ for $62.5 \mathrm{~A}-37.5 \mathrm{FL}$ mixture. The shift of the position of the band at lower wavenumbers could be due to an increase in the content of non-bridging oxygens or an increase in the extent of Al incorporation into the gel structure (Hajimohammadi et al., 2011). In 62.5A-37.5FL sample, where the percentage of $\mathrm{SiO}_{2}$ was higher, the appearance of band at higher wavenumbers could be expected, but this did not occur and therefore, an increase in non-bridging oxygens could have taken place. In addition, the intensity of this band was the highest in $62.5 \mathrm{~A}-37.5 \mathrm{FL}$ sample, higher amount of main reaction product was formed. The second band appeared at $456 \mathrm{~cm}^{-1}$ (peak 34), increasing its intensity with the amount of fluorescence lamp waste in the sample, coming to mask the peak at $475 \mathrm{~cm}^{-1}$ (peak 33) associated to muscovite. The intensity of peaks ascribed to vibrations generated by brucite and pirssonite also decreased with the increase of content of fluorescence lamp waste in the mixture, in agreement with the XRD results. The band in the range of $1486-1428 \mathrm{~cm}^{-1}$ (peak 18) showed clearly two peaks in the spectrum of $87.5 \mathrm{~A}-12.5 \mathrm{FL}$ sample, associated to the modes of $\mathrm{CO}_{3}{ }^{2-}$ in pirssonite $\left(1486 \mathrm{~cm}^{-1}\right)$ and in calcite $\left(1428 \mathrm{~cm}^{-1}\right)$, while this band only presented a peak in the spectrum of $62.5 \mathrm{~A}-37.5 \mathrm{FL}$ mixture $\left(1450 \mathrm{~cm}^{-1}\right)$, ascribed to calcite. Thermonatrite, sodium carbonate, was not detected in the FTIR spectra because its main vibration bands overlapped with the vibration modes of calcite or dolomite.

The infrared spectrum for 75A-25FL-2 sample is reproduced in figure 4(b). The most relevant finding in this spectrum was the shift observed in the T-O band, recorded to $1007 \mathrm{~cm}^{-1}$ (peak 21). This shift was indicated of changes in the $\mathrm{Si} / \mathrm{Al}$ ratio in the chief reaction product, in this case an enrichment of gel in aluminium was favoured. The position of this band in the analogous sample activated with poorer- $\mathrm{Al} \mathrm{NaOH}$ solution waste was at $1017 \mathrm{~cm}^{-1}$, where a lower extent of Al substitution in the $\mathrm{C}-\mathrm{S}-\mathrm{H}$ gel took place. FTIR analysis confirmed the presence of the main vibration types of katoite hydrogrossular: 3664 (O-H stretching vibration, peak 2), 796 and $537 \mathrm{~cm}^{-1}$ (two lattice vibrations, peaks 24 and 31) (Kolesov and Geiger, 2005), and the absence of vibrations of pirssonite and brucite.

3.2.3. Environmental scanning electron microscopy (ESEM) and energy dispersive X-ray microanalysis (EDX) 
Figure 5 shows SEM images of 100FL and 100A samples. The matrix of 100FL was totally smooth with a uniform microstructure, similar to a glass, in which some microcracks were observed. These cracks are due to the high shrinkage of silica-rich samples $\left(\mathrm{SiO}_{2}=67.8 \%\right)$ and they have also been observed when activating ceramic frits with a high quantity of silica in their composition (information not presented in this work) (Arulrajah et al., 2016; GarciaLodeiro et al., 2014; Kourti et al., 2011). The matrix of 100A presented a greater degree of heterogeneity with undissolved fines particles such as calcite, dolomite and quartz, which agreed with the worst mechanical performance reported for this mixture (see 3.3 section). In this case, cracks do not appear due to the low silica content in the matrix $\left(\mathrm{SiO}_{2}=7.3 \%\right)$. The EDS analysis (Table 5) and the EDS maps (not shown) showed the main elements present in both matrix were $\mathrm{Si}, \mathrm{Na}, \mathrm{Al}, \mathrm{Ca}, \mathrm{Mg}$ and $\mathrm{O}$ and $\mathrm{K}$, which are related to the elemental composition of starting material and the alkaline activator. $\mathrm{Si}$ and $\mathrm{Na}$ were the main components detected in 100FL specimen, while $\mathrm{Ca}$ was found in smaller quantities. 100A specimen showed high contents of $\mathrm{Ca}$ and $\mathrm{Na}$ and a low content of $\mathrm{Si}$.

Figure 5. SEM images (2000x) of the alkali-activated samples: (a) 100FL, (b) 100A, (c) 87.5A12.5FL, (d) 75A-25FL, (e) 63.5A-37.5FL and (f) 75A-25FL-2.

Table 5. Energy dispersive X-ray spectroscopy (EDS) data of the different gels in the samples.

The microstructure of $87.5 \mathrm{~A}-12.5 \mathrm{FL}, 75 \mathrm{~A}-25 \mathrm{FL}$ and $62.5 \mathrm{~A}-37.5 \mathrm{FL}$ specimens is shown in figure 5(c), (d) and (e). It was observed a certain degree of heterogeneity, with larges particles of unreacted asphalt filler particles surrounded by the alkali-activation reaction products (dark area). An increase of content of FL waste leaded to a denser and more compact reaction product, what impact on the bending strength, as discussed later. It should be noted that when A waste is added, cracks do not appear probably due to the lower shrinkage during the curing stage. In these samples, the EDS maps showed $\mathrm{Si}, \mathrm{Na}$ and $\mathrm{Ca}$ as the main components. As an example, figure 6 shows the EDS map for 75A-25FL sample. Four distinctive areas could be identified in this image, Ca-rich (calcite), $\mathrm{Ca}$ and $\mathrm{Mg}$-rich (dolomite), $\mathrm{Si}$ and O-rich (quartz) and a homogeneous matrix containing $\mathrm{Si}, \mathrm{Al}, \mathrm{Ca}$ and $\mathrm{Na}$, consistent with a gel of calcium silicate hydrate with $\mathrm{Al}$ and $\mathrm{Na}$ in its structure, which agreed with the results obtained by XRD and FTIR.

Figure 6. EDS maps showing the microstructure of 75A-25FL sample and partitioning of key elements. 
SEM image of 75A-25FL-2 (Figure 5(f)), prepare with high $\mathrm{NaOH}$ molarity (9.9 M), presented a heterogeneous microstructure, similar to that of the specimen 75A-25FL. However, the microstructure of the reaction product seemed different, in this sample it had less compaction and continuity due to the fact that the $\mathrm{NaOH}$ waste solution used in this composition had a high quantity of aluminium dissolved in. In addition, $\mathrm{Si} / \mathrm{Al}$ and $\mathrm{Na} / \mathrm{Al}$ ratios for this sample were lower than those obtained for 75A-25FL specimen (Table 5) and it is because the largest amount of dissolved aluminium. Although, a high content of Al, which is one of the main elements required for the formation of aluminosilicate bonds, was detected in 75A-25FL-2 sample, the final strength of the specimens did not change markedly (see 3.3 section).

\subsection{Aspect of the alkali-activated samples, bulk density, bending strength and water absorption}

Figure 7 shows the images of the specimens before characterisation. 100FL are full of cracks, some of them comes through the piece, breaking it (Figure 7(a)). 100A have an irregular colour, but they are entire and their edges depict a complete parallelepiped (Figure 7(b)). When FL is added to the composition (Figure 7(c), (d) and (e)), the brown colour is more homogeneous; however, by adding more amount of FL (Figure 7(e)), which is a white powder, the brown colour becomes less intense. Finally, the samples prepared with higher-molarity and richer-Al $\mathrm{NaOH}$ waste (Figure 7(f)) change the colour completely, possibly due to the formation of new aluminium compounds (see XRD pattern in figure 3(b) and FTIR spectrum in figure 4(b))

Figure 7. Specimens' photographs: (a) 100FL, (b) 100A, (c) 87.5A-12.5FL, (d) 75A-25FL, (e) 63.5A-37.5FL and (f) 75A-25FL-2.

Figure 78 shows the results of bulk density and bending strength of 10 tested specimens. The evolution of both properties with the FL content is quite similar, with a maximum around the composition with $25 \%$ of FL. The data of the composition 100FL is not included due to the presence of cracks in the test specimens, which are the result of an excessive shrinkage of the test specimens during the curing together with their stuck to the mould.

Regarding the bending strength, data for 100A (Figure 87) was quite low mainly due to the small silica content (7.3\%) in the asphalt fillers waste, since a certain quantity of silica is 
required to form the gel. When FL was added to the composition, bulk density and bending strength of the compositions raised due to the increase of silica in the network of the activated material. The increase of $\mathrm{SiO}_{2} / \mathrm{Al}_{2} \mathrm{O}_{3}$ ratio has positive effects on the strength since $\mathrm{Si}-\mathrm{O}-\mathrm{Si}$ bonds are stronger than $\mathrm{Si}-\mathrm{O}-\mathrm{Al}$ and $\mathrm{Al}-\mathrm{O}-\mathrm{Al}$ bonds, it is expected that the strength of the activated mixtures will increase (Bobirică et al., 2015; Novais et al., 2016). This trend reached a maximum (around 75A-25FL), and then both properties, apparent density and mechanical resistance, decreased as it is observed in figure 78. This decrease in both parameters could be due to an excess of the amount of silica required, in agreement with the lower activation degree presented in high silica glasses (Arulrajah et al., 2016; Garcia-Lodeiro et al., 2014; Kourti et al., 2011).

Figure 78. Bulk density and bending strength vs FL addition.

In the case of the sample activated with higher-molarity and richer- $\mathrm{Al} \mathrm{NaOH}$ waste (75A25FL-2), although the higher $\mathrm{NaOH}$ concentration is more effective in dissolving aluminosilicate particles and the higher $\mathrm{Al}$ dissolved in the $\mathrm{NaOH}$ waste promotes the formation of aluminium compounds (see XRD pattern in figure 3(b) and FTIR spectrum in figure 4(b)), the bending strength values did not change noticeably (Table 6).

Table 6. Bulk density and mechanical bending strength of the same composition activated with different $\mathrm{NaOH}$ waste solutions.

Table 7 shows the minimum bending strength requirements for the different performance classes corresponding to concrete tiles used as urban pavement. Comparing the bending strength data of the compositions tested with these data in Table 6 , it is observed that the specimens prepared with the wastes showed higher values than the ones required by the standard. That is the reason why these alkali-activated materials could be used for urban paving.

Table 7. Performance classes and marking of concrete tiles for urban pavement, according to standards UNE-EN 1339:2004 and UNE 127339:2007 (UNE-EN 1339 2004; UNE 127339:2007, 2007). 

Regarding the water absorption, these values are ranged between 15 and 25\% (Table 8), taking into account that samples with higher mechanical strengths (75A-25FL and 75A-25FL-2) lead to samples with lower water absorption, and vice versa. Note that water absorption could not be determined in 100FL specimens due to the cracks.

\section{Table 8. Water absorption of the alkali-activated samples.}

\subsection{Leachability test}

Leachability test were carried out with the sample that provided the highest values of bending strength, 75A-25FL.

Comparing the list of elements described in the guidelines set out in the Council Decision 2003/33/EC of 19 December 2002 and the Article 16 and Annex II to Directive 1999/31/CEE (Council Decision 2003/33/EC, 2003) (see 2.3. section) with the elements contained in the starting waste materials (Table 2), the elements analysed in the leachate were: barium, lead and sulphates.

All of them $\left(\mathrm{Ba}, \mathrm{Pb}\right.$ and $\left.\mathrm{SO}_{4}{ }^{2-}\right)$ come from $\mathrm{FL}$ waste, since their quantities in $\mathrm{A}$ and $\mathrm{NaOH}$ wastes are lower than $0.01 \%$ (Table 2). The comparison of $\mathrm{BaO}, \mathrm{PbO}$ and $\mathrm{S}$ content in the starting composition with the values determined in the leachate (Table 98), allows to conclude that almost the whole amount (>99.9\%) of $\mathrm{Ba}$ and $\mathrm{Pb}$ have been encapsulated in the network of the alkali-activated material. In the case of sulphate, the amount retained was a little lower: $539 \mathrm{mg} / \mathrm{kg}$ in the leachate with respect to $2400 \mathrm{mg} / \mathrm{kg}$ in the FL starting powder; that is, $77.5 \%$.

Table 98 shows the maximum limits allowed by the regulation regarding the type of waste and the results obtained for sample 75A-25FL. It can be concluded that activated material obtained can be classified as inert.

Table 28. Maximum values allowed for different types of landfill waste and results of the characterised sample. Leaching test according to the standard UNE-EN 12457-2, Part 2 (UNEEN 12457-2:2003, 2003). 


\section{Conclusions}

This paper deals with alkaline activated materials obtained exclusively with industrial and urban wastes both, for the aluminosilicate solid and the alkaline solution.

The dosage of solid waste and the concentration and composition of alkaline activator play an important role in the mineralogy and microstructure the alkali-activated materials obtained. In this study, an increase of the percentage of fluorescent lamp waste to the detriment of asphalt fines waste in the binders meant the formation of single sodium carbonates and the development of a microstructure denser and more compacted.

The use of an alkaline activator, sodium hydroxide, with a higher concentration and a greater amount of aluminium promoted the formation of crystalline aluminium compounds and the enrichment in aluminium of the calcium silicate hydrate gel. The microstructure of the matrix had less compaction and continuity, but its Al content was high, favouring the formation of aluminosilicate bonds. However, this content was not enough to improve the bending strength.

When FL is added to A composition, bending strength raises due to the increase of silica in the network of the activated material, reaching a maximum in 75A-25FL composition; in this instance, bending strength is 5.6 times higher than the one measured in specimens without FL (100A). Bending strength values of the alkaline activated products obtained point out that they can be used for urban paving. In addition, leaching tests show the effectiveness of this process for retain heavy metals in the network formed. 
464 Acknowledgements

465 The work has been carried out thanks to a project, with reference IMAMCA/2016/1 466 IMDEEA/2017/100, co-financed by the IVACE and the ERDF Funds, within the ERDF 467 Operational Programme of the Valencia Region 2014-2020.

468 Maria Criado expresses her gratitude to the European Research Council under the European 469 Union's Seventh Framework Programme (FP/2007-2013)/ERC Grant Agreement \#335928. 470 Moreover, this research has performed in part at the MIDAS Facility, at The University of 471 Sheffield, which was stablished with support from the Department of Energy and Climate 472 Change. 
References

Arulrajah, A., Kua, T.-A., Horpibulsuk, S., Phetchuay, C., Suksiripattanapong, C., Du, Y.-J., 2016. Strength and microstructure evaluation of recycled glass-fly ash geopolymer as low-carbon masonry units. Constr. Build. Mater 114, 400406.https://doi.org/10.1016/j.conbuildmat.2016.03.123

Bobirică, C., Shim, J.-H., Pyeon, J.-H., Park, J.-Y., 2015. Influence of waste glass on the microstructure and strength of inorganic polymers. Ceram. Int. 41(10, Part A), 1363813649.https://doi.org/10.1016/j.ceramint.2015.07.160

Buchwald, A., Vicent, M., Kriegel, R., Kaps, C., Monzó, M., Barba, A., 2009. Geopolymeric binders with different fine fillers - phase transformations at high temperatures. Appl. Clay Sci. 46(2), 190195.https://doi:10.1016/j.clay.2009.08.002

COM (2015) 614 final, 2015. Communication from the commission to the European Parliament, the Council, the European Economic and Social Committee and the Committee of the Regions Closing the loop-An EU action plan for the Circular Economy 2015. European Commission (EC) COM (2017) 33 final, 2017. Report from the Commission to the European Parliament, the Council, the European Economic and Social Committee and the Committee of the Regions on the implementation of the Circular Economy Action Plan 2017. European Commision (EC)

Council Decision 2003/33/EC, 2003. Council Decision 2003/33/EC of 19 December 2002 establishing criteria and procedures for the acceptance of waste at landfills persuant to Article 16 of and Annex II to Directive 1999/31/EC. Official Journal of the European Communities 16(2003), L11

Criado, M., Fernández Jiménez, A., Sobrados, I., Palomo, A., Sanz, J., 2012. Effect of relative humidity on the reaction products of alkali activated fly ash. J. Eur. Ceram. Soc. 32(11), 27992807.http://dx.doi.org/10.1016/i.jeurceramsoc.2011.11.036

Fernández-Jiménez, A., Monzó, M., Vicent, M., Barba, A., Palomo, A., 2008. Alkaline activation of metakaolin-fly ash mixtures: obtain of zeoceramics and zeocements. Microporous Mesoporous Mat. 108(1-3), 41-49.http://doi:10.1016/i.micromeso.2007.03.024

Fernández-Jiménez, A., Palomo, A., 2003. Characterisation of fly ashes. Potential reactivity as alkaline cements. Fuel 82(18), 2259-2265.https://doi.org/10.1016/S0016-2361(03)00194-7

Frías, M., De Rojas, M.S., García, R., Valdés, A.J., Medina, C., 2012. Effect of activated coal mining wastes on the properties of blended cement. Cem. Concr. Compos. 34(5), 678683.https://doi:10.1016/i.cemconcomp.2012.02.006

Frost, R.L., Dickfos, M., 2007. Hydrated double carbonates - A Raman and infrared spectroscopic study. Polyhedron 26(15), 4503-4508.https://doi.org/10.1016/j.poly.2007.06.003

Frost, R.L., Kloprogge, J.T., 1999. Infrared emission spectroscopic study of brucite. Spectrochim. Acta Part A: Molec. Biomolec. Spectr. 55(11), 2195-2205.https://doi.org/10.1016/S13861425(99)00016-5

Gadsden, J., 1975. Infrared Spectra of Minerals and Related Inorganic Compounds. Batterworths.

García-Lodeiro, I., Fernández-Jiménez, A., Blanco, M.T., Palomo, A., 2008. FTIR study of the sol-gel synthesis of cementitious gels: C-S-H and N-A-S-H. J. Sol-Gel Sci. Techn. 45(1), 6372.https://doi.org/10.1007/s10971-007-1643-6

Garcia-Lodeiro, I., Fernández-Jimenez, A., Pena, P., Palomo, A., 2014. Alkaline activation of synthetic aluminosilicate glass. Ceram. Int. 40(4), 55475558.https://doi.org/10.1016/j.ceramint.2013.10.146

Görhan, G., Kürklü, G., 2014. The influence of the $\mathrm{NaOH}$ solution on the properties of the fly ash-based geopolymer mortar cured at different temperatures. Compos. Part B: Eng. 58, 371377.http://dx.doi.org/10.1016/j.compositesb.2013.10.082

Hajimohammadi, A., Provis, J.L., Van Deventer, J.S., 2011. Time-resolved and spatially-resolved infrared spectroscopic observation of seeded nucleation controlling geopolymer gel formation. J. Colloid Interf. Sci. 357(2), 384-392.https://doi:10.1016/j.jcis.2011.02.045 
Hwang, C.-L., Huynh, T.-P., 2015. Effect of alkali-activator and rice husk ash content on strength development of fly ash and residual rice husk ash-based geopolymers. Constr. Build. Mater 101, 1-9.http://dx.doi.org/10.1016/j.conbuildmat.2015.10.025

Jelić, I., Šljivić-Ivanović, M., Dimović, S., Antonijević, D., Jović, M., Mirković, M., Smičiklas, I., 2018. The applicability of construction and demolition waste components for radionuclide sorption. J. Clean. Prod. 171, 322-332.https://doi.org/10.1016/i.jclepro.2017.09.220

Kolesov, B.A., Geiger, C.A., 2005. The vibrational spectrum of synthetic hydrogrossular (katoite) Ca3Al2 (O4H4) 3: A low-temperature IR and Raman spectroscopic study. Am. Mineral. 90(8-9), 13351341.https://doi.org/10.2138/am.2005.1622

Komnitsas, K., Zaharaki, D., Vlachou, A., Bartzas, G., Galetakis, M., 2015. Effect of synthesis parameters on the quality of construction and demolition wastes (CDW) geopolymers. Adv. Powder Technol. 26(2), 368-376.https://doi.org/10.1016/i.apt.2014.11.012

Kourti, I., Devaraj, A.R., Bustos, A.G., Deegan, D., Boccaccini, A.R., Cheeseman, C.R., 2011. Geopolymers prepared from DC plasma treated air pollution control (APC) residues glass: properties and characterisation of the binder phase. J. Hazard. Mater. 196, 8692.http://doi:10.1016/j.jhazmat.2011.08.081

Lancellotti, I., Kamseu, E., Michelazzi, M., Barbieri, L., Corradi, A., Leonelli, C., 2010. Chemical stability of geopolymers containing municipal solid waste incinerator fly ash. Waste Manage. 30(4), 673-679.http://doi:10.1016/j.wasman.2009.09.032

Mijarsh, M., Johari, M.M., Ahmad, Z.A., 2015. Compressive strength of treated palm oil fuel ash based geopolymer mortar containing calcium hydroxide, aluminum hydroxide and silica fume as mineral additives. Cem. Concr. Compos. 60, 81.http://dx.doi.org/10.1016/i.cemconcomp.2015.02.007

Novais, R.M., Ascensão, G., Seabra, M.P., Labrincha, J.A., 2016. Waste glass from end-of-life fluorescent lamps as raw material in geopolymers. Waste Manage. 52, 245255.https://doi.org/10.1016/j.wasman.2016.04.003

Palomo, A., Grutzeck, M.W., Blanco, M.T., 1999. Alkali-activated fly ashes: A cement for the future. Cem. Concr. Res. 29(8), 1323-1329.http://dx.doi.org/10.1016/S0008-8846(98)00243-9

Ryu, G.S., Lee, Y.B., Koh, K.T., Chung, Y.S., 2013. The mechanical properties of fly ash-based geopolymer concrete with alkaline activators. Constr. Build. Mater 47, 409418.https://doi.org/10.1016/i.conbuildmat.2013.05.069

Santa, R.A.A.B., Bernardin, A.M., Riella, H.G., Kuhnen, N.C., 2013. Geopolymer synthetized from bottom coal ash and calcined paper sludge. J. Clean. Prod. 57, 302307.http://dx.doi.org/10.1016/i.jclepro.2013.05.017

Shearer, C.R., Provis, J.L., Bernal, S.A., Kurtis, K.E., 2016. Alkali-activation potential of biomass-coal cofired fly ash. Cem. Concr. Compos. 73, 6274.http://dx.doi.org/10.1016/j.cemconcomp.2016.06.014

Silverstein, R.M., Webster, F.X., Kiemle, D.J., Bryce, D.L., 2014. Spectrometric identification of organic compounds. John wiley \& sons.

Soutsos, M., Boyle, A.P., Vinai, R., Hadjierakleous, A., Barnett, S.J., 2016. Factors influencing the compressive strength of fly ash based geopolymers. Constr. Build. Mater 110, 355368.https://doi.org/10.1016/i.conbuildmat.2015.11.045

Tchadjié, L., Djobo, J., Ranjbar, N., Tchakouté, H., Kenne, B., Elimbi, A., Njopwouo, D., 2016. Potential of using granite waste as raw material for geopolymer synthesis. Ceram. Int. 42(2), 30463055.http://dx.doi.org/10.1016/j.ceramint.2015.10.091

Tchakouté, H., Elimbi, A., Yanne, E., Djangang, C., 2013. Utilization of volcanic ashes for the production of geopolymers cured at ambient temperature. Cem. Concr. Compos. 38, 75-81

Tchakouté, H.K., Rüscher, C.H., Kong, S., Kamseu, E., Leonelli, C., 2016. Comparison of metakaolinbased geopolymer cements from commercial sodium waterglass and sodium waterglass from rice husk ash. J. Sol-Gel Sci. Technol. 78(3), 492-506.http://DOI:10.1007/s10971-016-3983-6 
574 Torres-Carrasco, M., Puertas, F., 2015. Waste glass in the geopolymer preparation. Mechanical and characterisation.

J.

Clean.

Prod.

90 ,

397408.http://dx.doi.org/10.1016/j.jclepro.2014.11.074

UNE-EN 1339 2004. Concrete paving Flags - Requirements and Test Methods. Spanish Association for Standardization and Certification

UNE-EN 12457-2:2003, 2003. Characterisation of waste - Leaching - Compliance test for leaching of granular waste materials and sludges - Part 2: One stage batch test at a liquid to solid ratio of $10 \mathrm{l} / \mathrm{kg}$ for materials with particle size below $4 \mathrm{~mm}$ (without or with size reduction).

UNE 127339:2007, 2007. Properties and conditions of suppy and reception of concrete tiles.

Vaculikova, L., Plevova, E., 2005. Identification of clay minerals and micas in sedimentary rocks. Acta Geodyn. Geomater. 2(2), 167-175

Zheng, L., Wang, C., Wang, W., Shi, Y., Gao, X., 2011. Immobilization of MSWI fly ash through geopolymerization: effects of water-wash. Waste Manage. 31(2), 311317.http://doi:10.1016/j.wasman.2010.05.015 
María Criado Sanz, BSC and PhD degrees in Chemistry

Research Associate, Instituto de Ciencias de la Construcción Eduado Torroja

Department of Construction, C/Serrano Galvache, 4

28033, Madrid, Spain

Prof. Dr. Jiří Jaromír Klemeš,

Editor-in-Chief, Journal of Cleaner Production

Brno University of Technology (VUT Brno),

Antonínská 548/1, Brno, Czech Republic

\section{Re: Manuscript submission for Journal of Cleaner Production}

Dear Professor Klemeš,

Accompanying this letter is a manuscript submitted for publication in Journal of Cleaner Production. This manuscript is written in a Regular Article, and is entitled "Alkaliactivated materials obtained from industrial wastes".

This manuscript represents an important role in the reutilisation and the viability of industrial wastes (fluorescence lamp, asphalt fine wastes and recycled $\mathrm{NaOH}$ ) in the construction field. Here, we carried out a deep and exhaustive characterisation of the raw materials and the new cementitious materials and their suitability for being used as urban pavement, both from mechanical and environmental points of view.

This work is both scientifically novel and industrially important, and is thus ideally suited to publication in Journal of Cleaner Production, as it brings a new application of industrial wastes as urban pavement.

I am pleased to confirm that the work described has not published before; it is not under consideration for publication anywhere else; and publication has been approved by all coauthors and the responsible authorities at the institutes where the work has been carried out.

Three potential referees, all experts in immobilisation and treatment of wastes in alkali cements: 
- Christopher R. Cheeseman, Department of Civil and Environmental Engineering, Imperial College London, London SW7 2AZ, UK, email: c.cheeseman@imperial.ac.uk

- Cristina Leonelli, Dipartimento di Ingegneria dei Materiali e dell'Ambiente, Università di Modena e Reggio Emilia, Via Vignolese 905, 41100 Modena, Italy. Email: cristina.leonelli@unimore.it

- H.K. Tchakouté. Laboratory of Applied Inorganic Chemistry, University of Yaounde I, Faculty of Science, Department of Inorganic Chemistry, B.P. 812, Yaounde, Cameroon. Email: htchak@yahoo.fr, hervetchakoute@gmail.com

Yours sincerely,

Maria Criado 


\section{Graphical Abstract}

$\mathrm{NaOH}$ waste
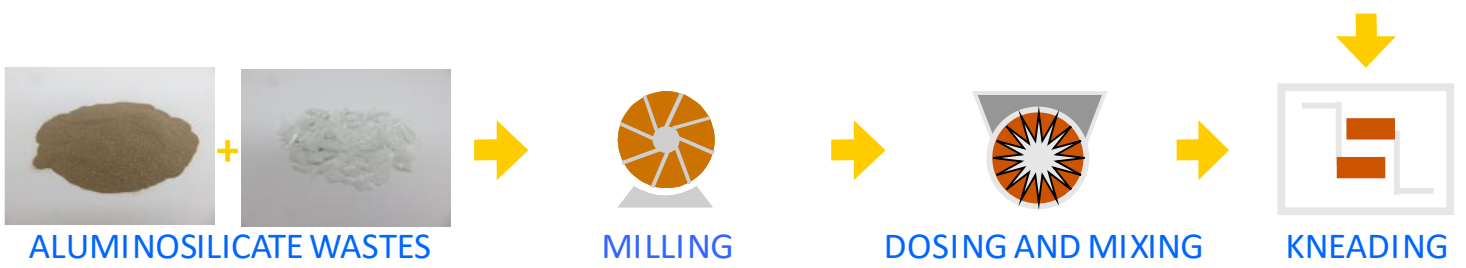

MILLING

DOSING AND MIXING

KNEADING

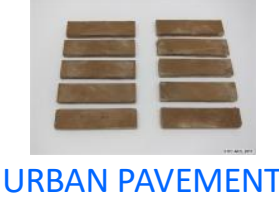

20

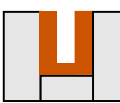

URBAN PAVEMENT

CURING

CASTING

$\mathrm{T}=\downarrow \downarrow \downarrow$

$\varphi=\uparrow \uparrow \uparrow$

Graphical abstract. Process' diagram 
Highlights.

- Lamp, asphalt fine and recycled $\mathrm{NaOH}$ were used to produce alkaline cements.

- Bending strength values demonstrated that they can be used as urban pavement.

- Leaching tests showed the effectiveness of this process for retain heavy metals. 


\section{FIGURE CAPTIONS}

Figure 1. Images of (a) original asphalt waste, (b) powder asphalt waste, (c) cut glass of fluorescent lamp waste and (c) powder fluorescent lamp waste.

Figure 2. Particle size distributions of A and FL milled powders.

Figure 3. XRD patterns of (a) the starting materials and (b) the activated materials.

Figure 4. FTIR spectra of (a) the starting materials and (b) the activated materials.

Figure 5. SEM images (2000x) of the alkali activated samples: (a) 100FL, (b) 100A, (c) 87.5A12.5FL, (d) 75A-25FL, (e) 63.5A-37.5FL and (f) 75A-25FL-2.

Figure 6. EDS maps showing the microstructure of 75A-25FL sample and partitioning of key elements.

Figure 7. Specimens' photographs: (a) 100FL, (b) 100A, (c) 87.5A-12.5FL, (d) 75A-25FL, (e) 63.5A-37.5FL and (f) 75A-25FL-2.

Figure 87 . Bulk density and bending strength vs FL addition. 

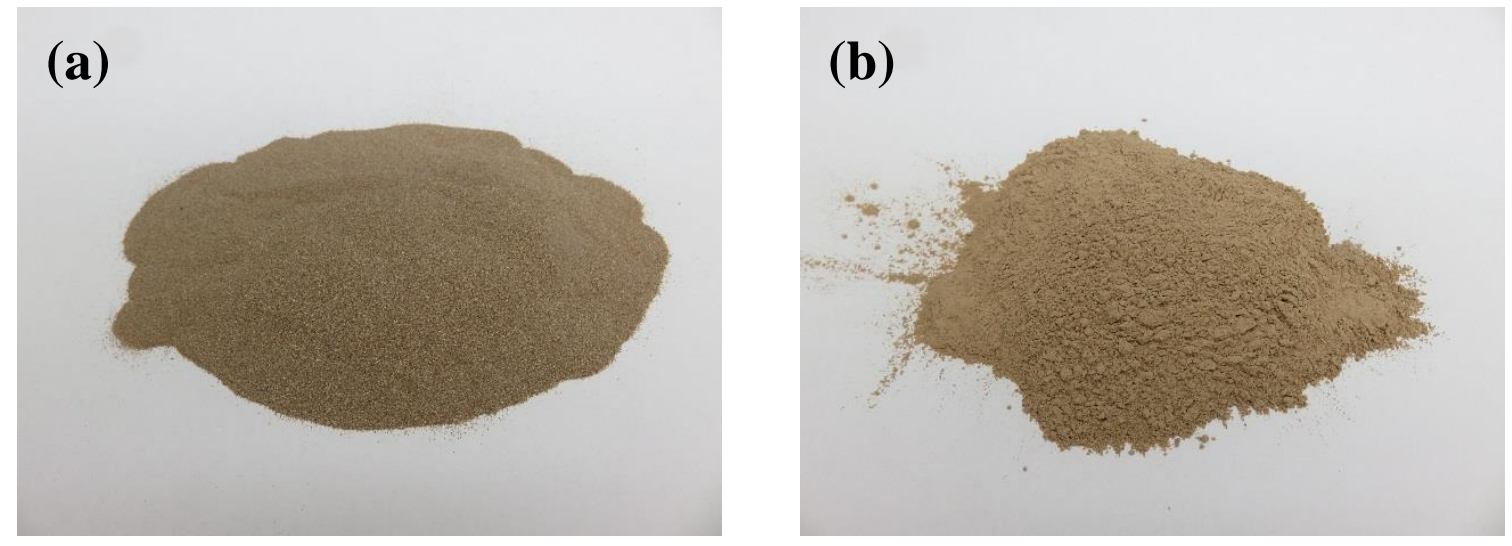

(c)

(d)

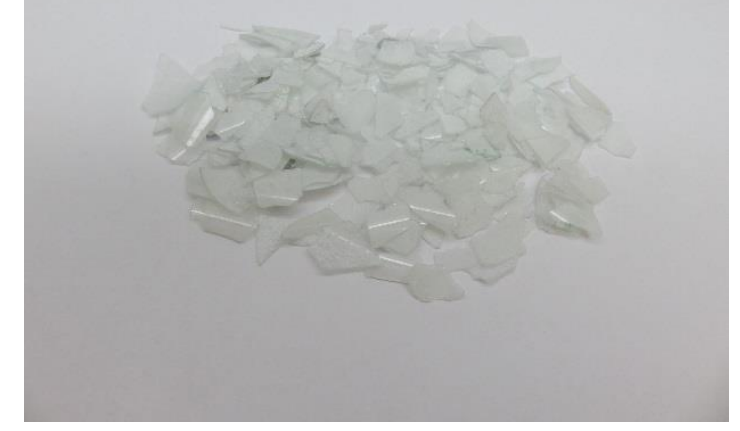

Figure 1. 


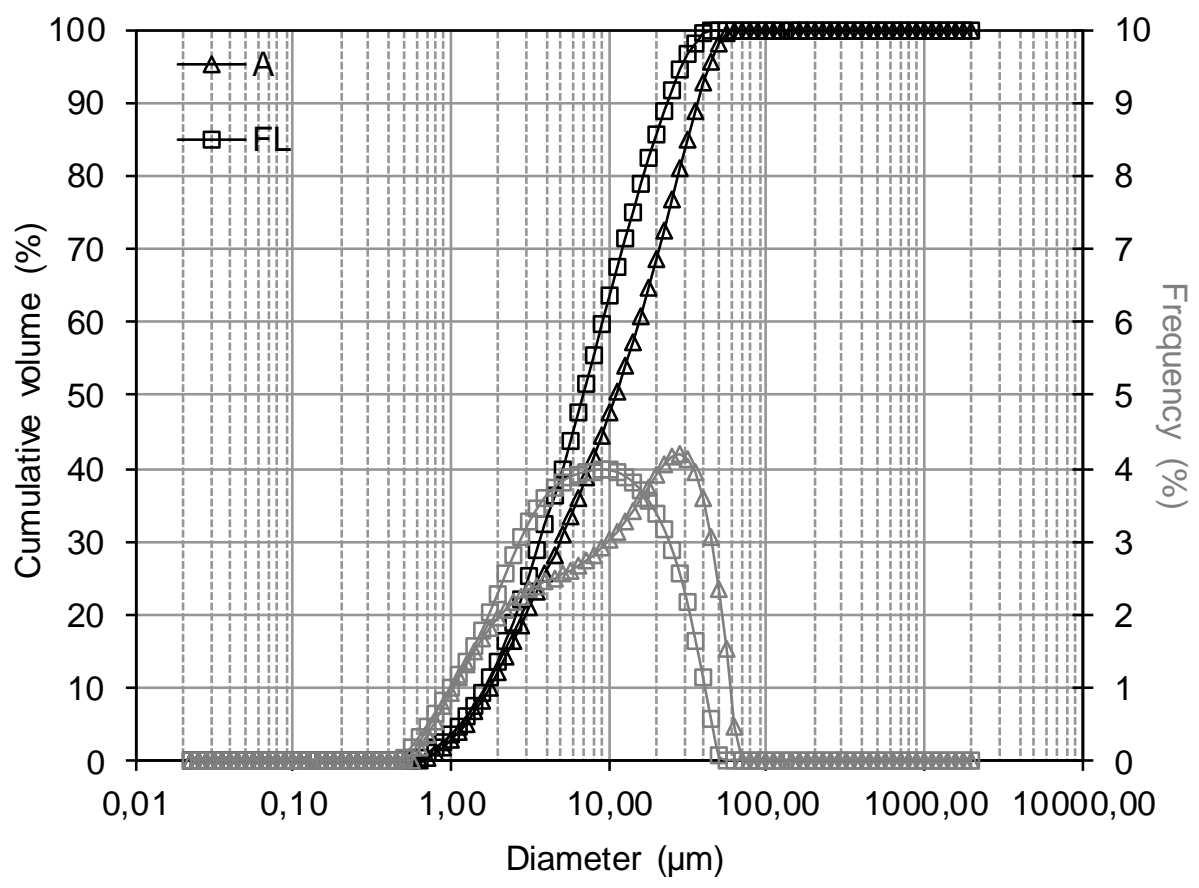

Figure 2. 
C-Calcite D-Dolomite Q-Quartz M-Muscovite
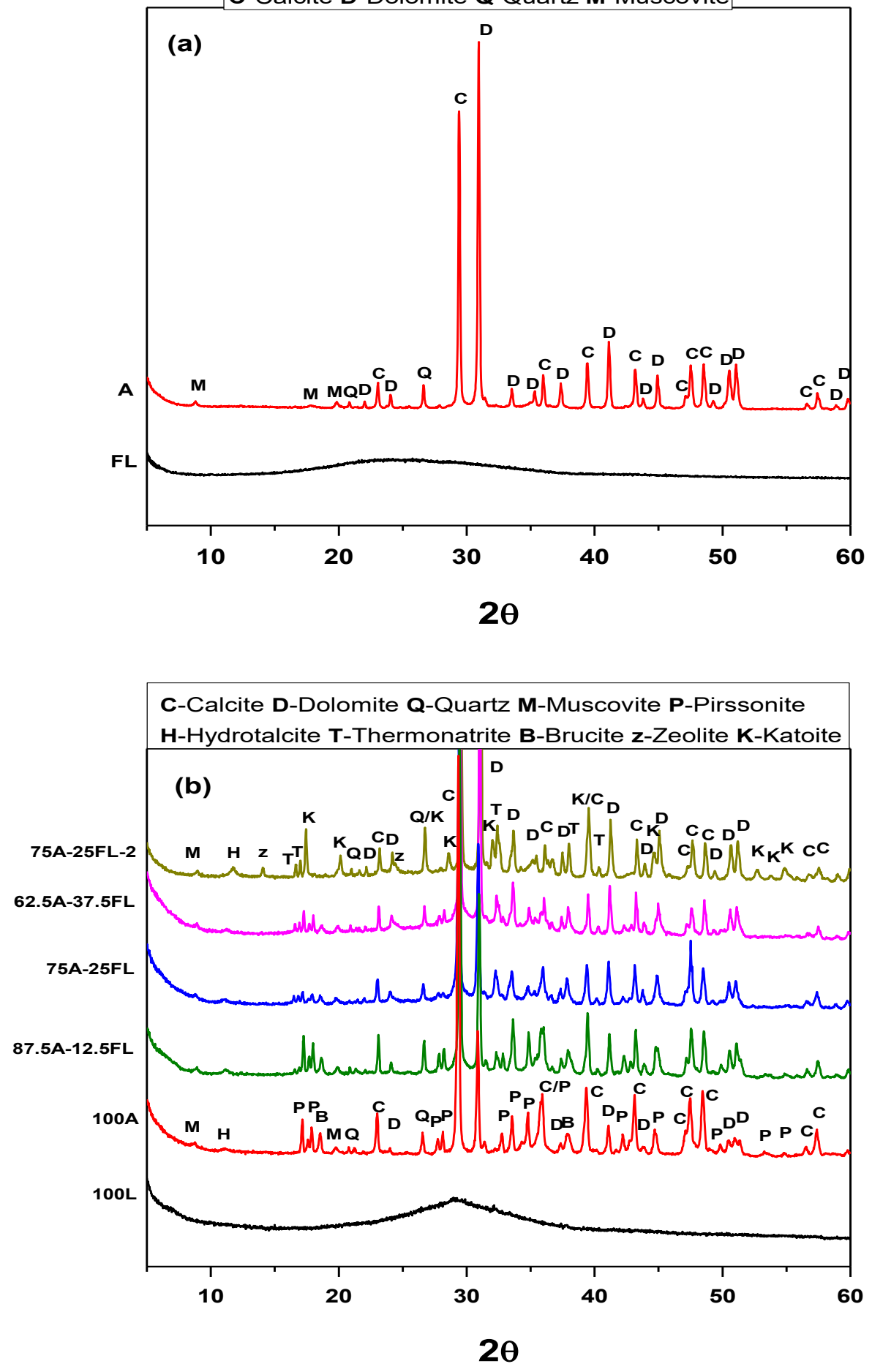

Figure 3. 

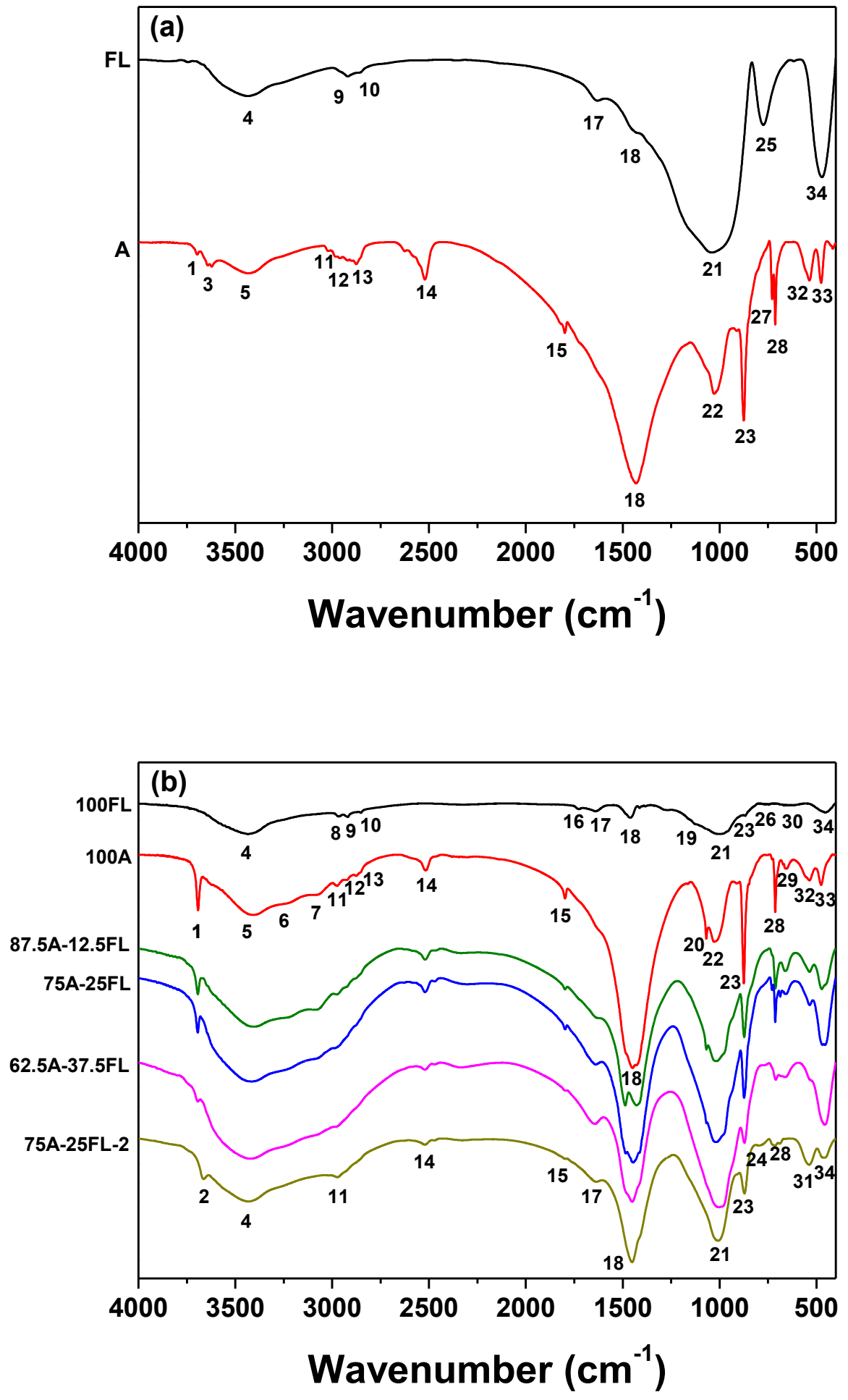

Figure 4. 

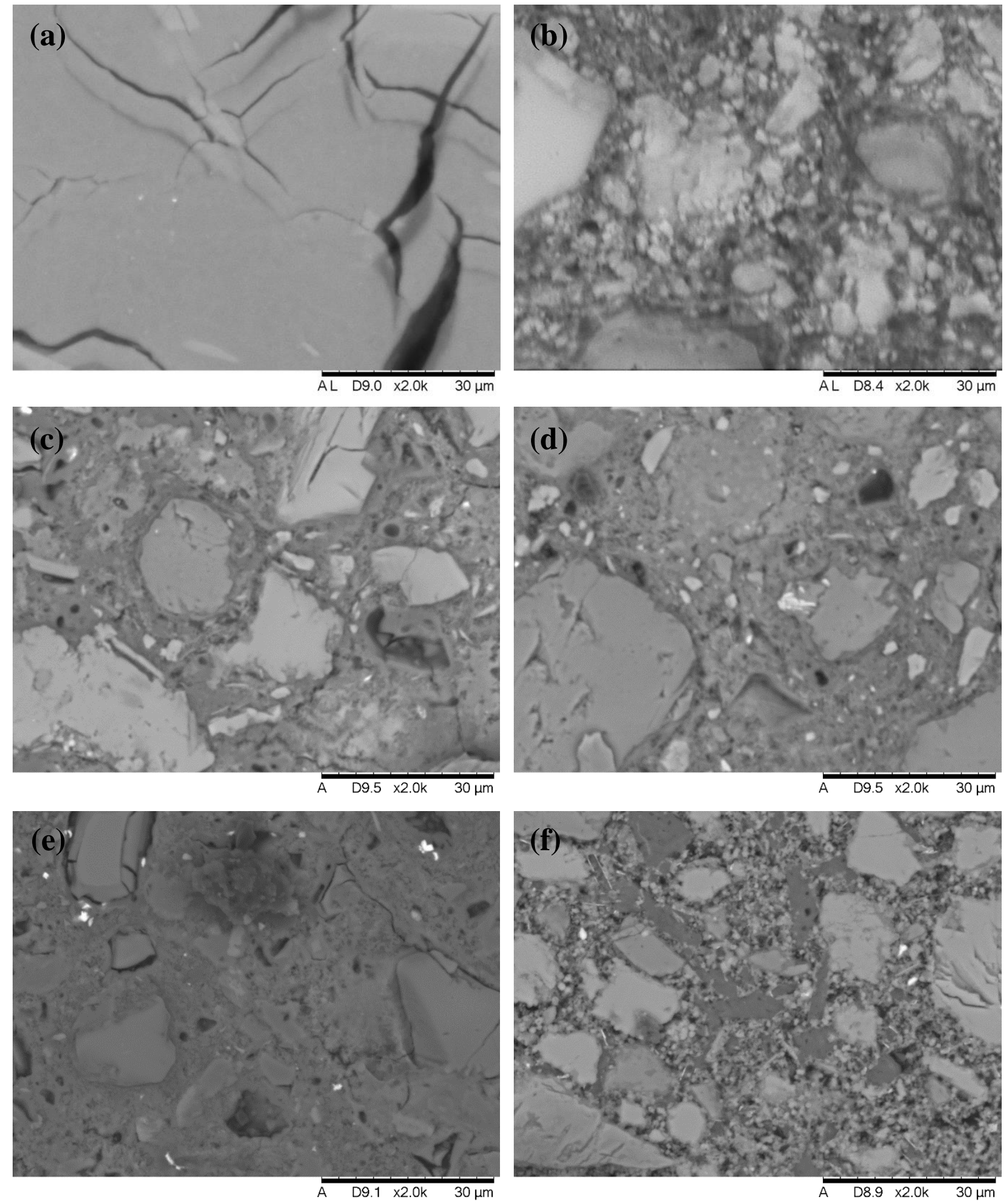

Figure 5. 


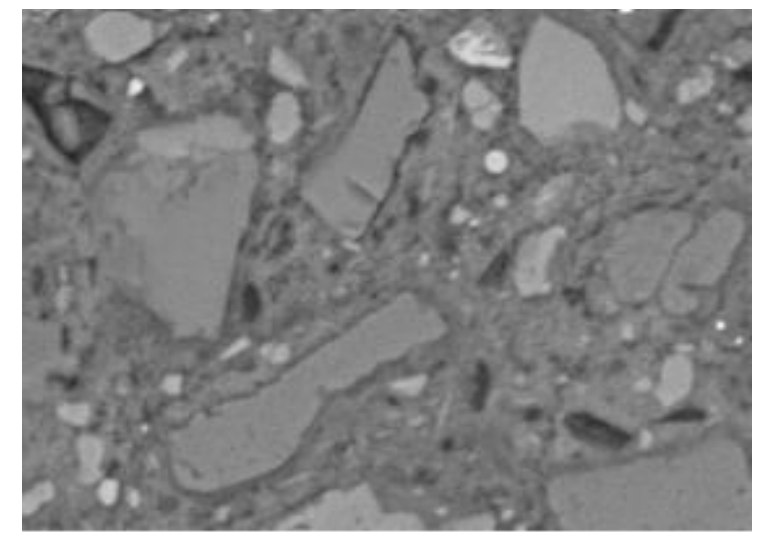

BSE
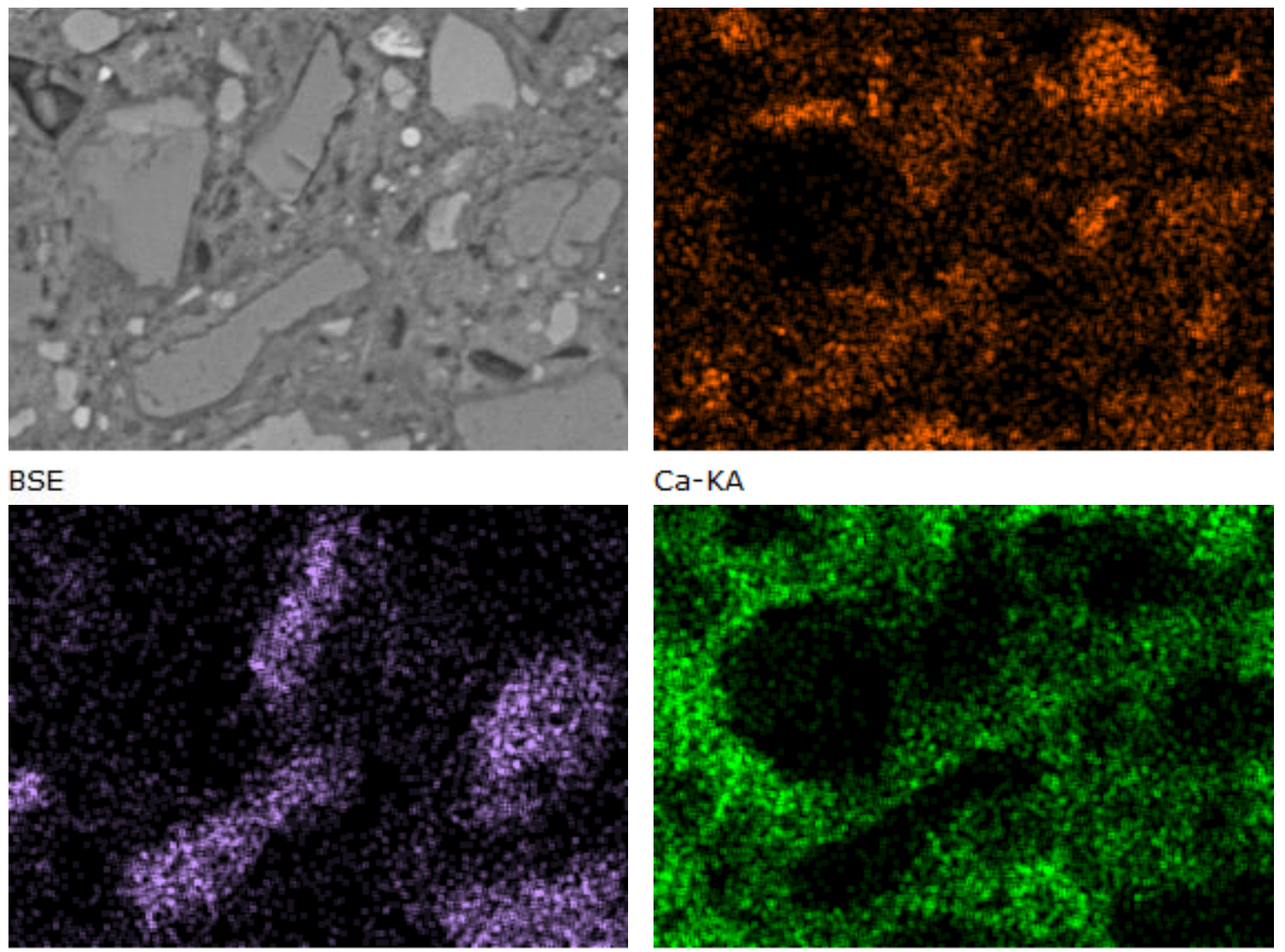

Ca-KA

Mg-K
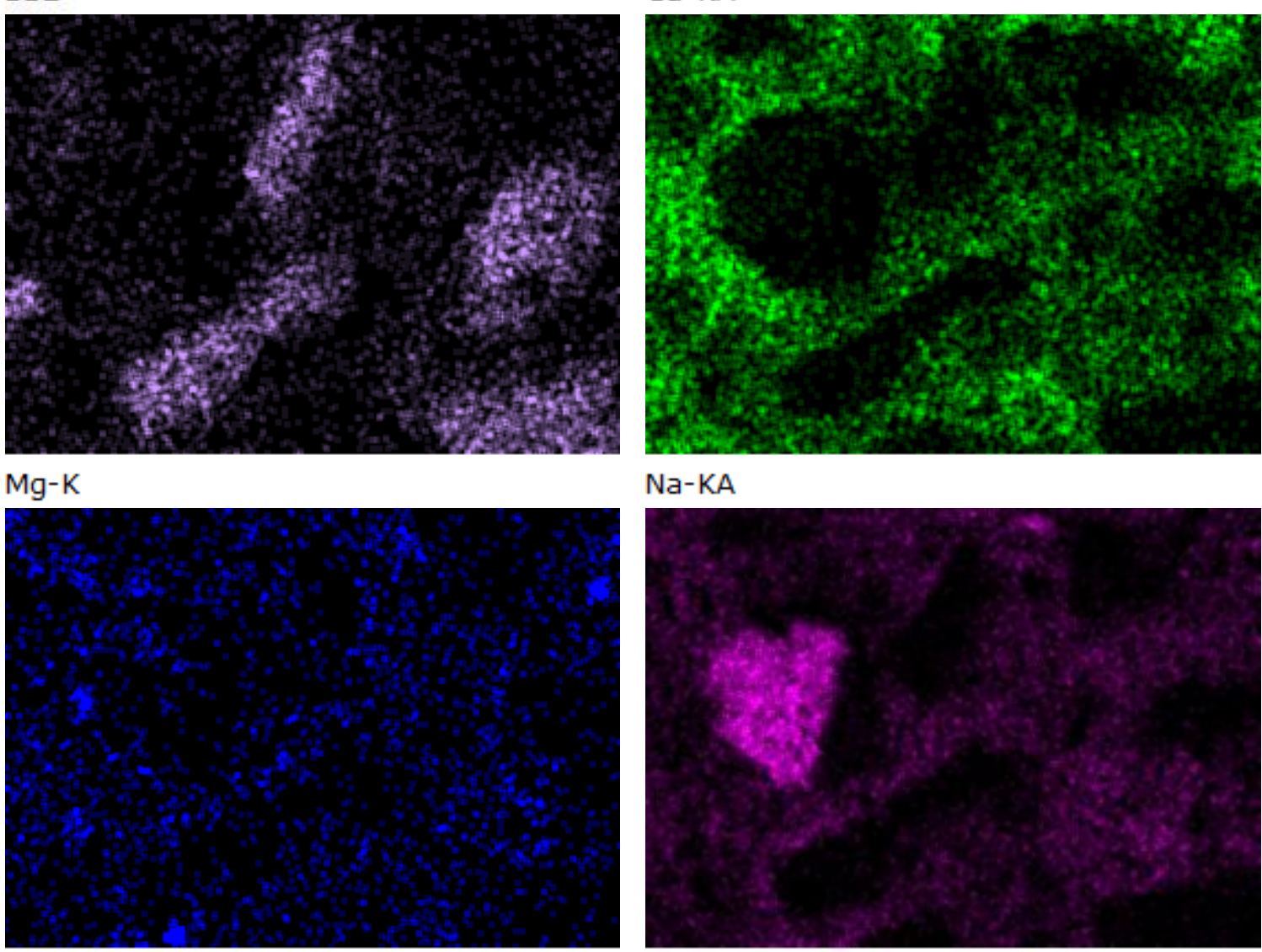

Al-K

$\mathrm{Na}-\mathrm{KA}$

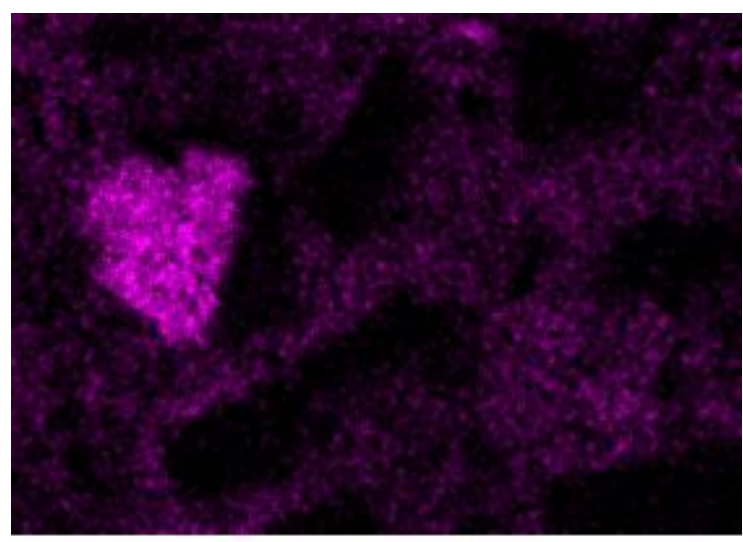

Figure 6.

Figure 6. 

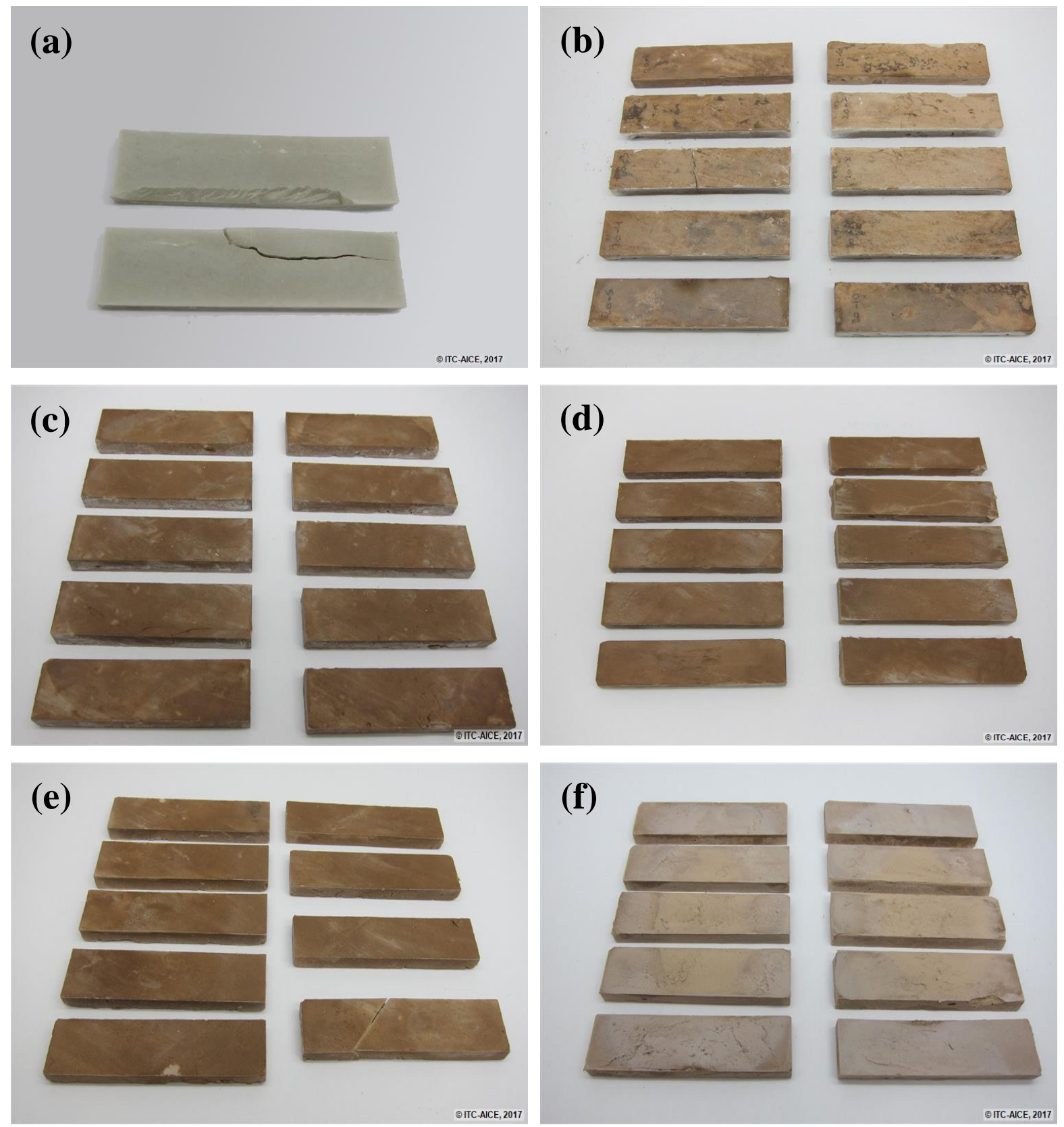

Figure 7. 


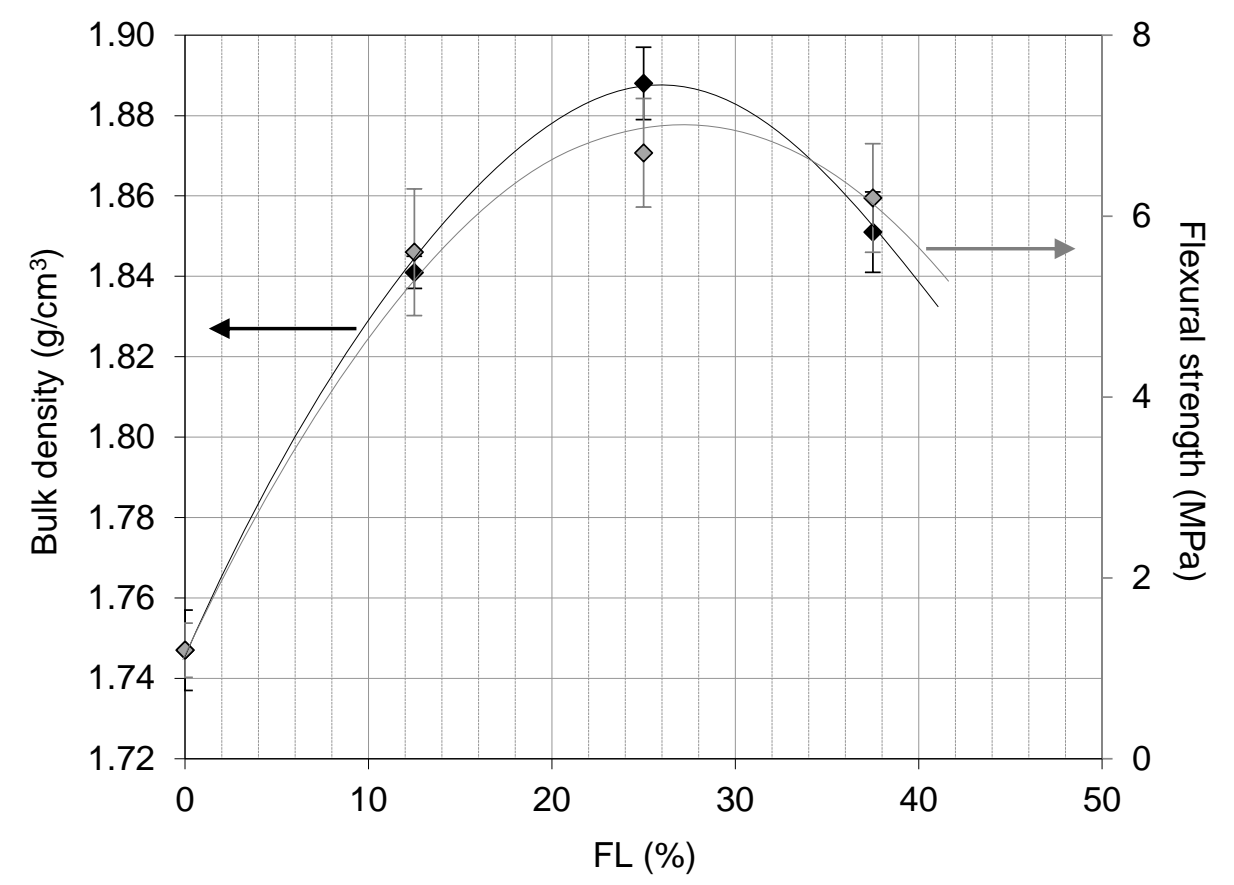

Figure 87. 


\section{TABLES}

Table 1. Compositions studied (\% by weight).

Table 2. Chemical composition of asphalt filler (A) and fluorescence lamp (FL) waste powders, and $\mathrm{NaOH}$ waste solution dried at $110^{\circ} \mathrm{C}$, determined by WD-XRF (\% by weight).

Table $3 . \mathrm{NaOH}$ waste molarity according to the storage time.

Table 4. Bands on the FTIR spectra of the starting materials and the activated materials.

Table 5. Energy dispersive x-ray spectroscopy (EDS) data of the different gels in the samples.

Table 6. Bulk density and mechanical bending strength of the same composition activated with different $\mathrm{NaOH}$ waste solutions.

Table 7. Performance classes and marking of concrete tiles for urban pavement, according to standards UNE-EN 1339:2004 and UNE 127339:2007 (UNE-EN 1339 2004; UNE 127339:2007, 2007).

\section{Table 8. Water absorption of the alkali-activated samples.}

Table 9. Maximum values allowed for different types of landfill waste and results of the characterised sample. Leaching test according to the standard UNE-EN 12457-2, Part 2 (UNEEN 12457-2:2003, 2003). 
Table 1. Compositions studied (\% by weight)

\begin{tabular}{|l|l|l|l|l|l|}
\hline Composition & $100 \mathrm{~A}$ & $100 \mathrm{FL}$ & $\begin{array}{l}87.5 \mathrm{~A}- \\
12.5 \mathrm{FL}\end{array}$ & $75 \mathrm{~A}-25 \mathrm{FL}$ & $\begin{array}{l}62.5 \mathrm{~A}- \\
37.5 \mathrm{FL}\end{array}$ \\
\hline $\mathrm{A}$ & 100 & - & 87.5 & 75 & 62.5 \\
\hline FL & - & 100 & 12.5 & 25 & 37.5 \\
\hline
\end{tabular}


Table 2. Chemical composition of asphalt filler (A) and fluorescence lamp (FL) waste powders, and $\mathrm{NaOH}$ waste solution dried at $110{ }^{\circ} \mathrm{C}$, determined by WD-XRF (\% by weight).

\begin{tabular}{|l|l|l|l|l|l|l|l|l|l|l|l|l|l|l|l|l|l|l|l|l|l|l|l}
\hline & $\mathrm{SiO}_{2}$ & $\mathrm{Al}_{2} \mathrm{O}_{3}$ & ${ }^{(1)} \mathrm{B}_{2} \mathrm{O}_{3}$ & $\mathrm{Fe}_{2} \mathrm{O}_{3}$ & $\mathrm{CaO}$ & $\mathrm{MgO}$ & $\mathrm{Na}_{2} \mathrm{O}$ & $\mathrm{K}_{2} \mathrm{O}$ & $\mathrm{TiO}_{2}$ & $\mathrm{ZrO}_{2}$ & $\mathrm{BaO}^{(2)} \mathrm{Li}_{2} \mathrm{O}$ & $\mathrm{PbO}$ & $\mathrm{ZnO}^{(3)}$ & $\mathrm{HfO}_{2}$ & $\mathrm{P}_{2} \mathrm{O}_{5}$ & $\mathrm{SrO}$ & $\mathrm{MnO}$ & $\mathrm{S}$ & ${ }^{2} \mathrm{LoI}$ \\
\hline $\mathrm{A}$ & 7.3 & 3.4 & - & 1.0 & 35.4 & 10.8 & 0.10 & 0.64 & 0.11 & $<0.01$ & $<0.01$ & - & $<0.01$ & $<0.01$ & $<0.01$ & 0.06 & $<0.01$ & 0.03 & $<0.01$ & 41.1 \\
\hline $\mathrm{FL}$ & 67.8 & 2.1 & 0.85 & 0.16 & 3.90 & 2.51 & 16.0 & 2.15 & 0.04 & 0.02 & 1.37 & 0.03 & 0.39 & $<0.01$ & $<0.01$ & 0.04 & 0.13 & $<0.01$ & 0.08 & 2.47 \\
\hline $\mathrm{NaOH}$ & 1.5 & 31.1 & - & 0.02 & 0.03 & $<0.01$ & 39.4 & 0.20 & $<0.01$ & $<0.01$ & $<0.01$ & - & $<0.01$ & $<0.01$ & $<0.01$ & 0.06 & $<0.01$ & $<0.01$ & $<0.01$ & 12.2 \\
\hline
\end{tabular}

${ }^{(1)} \mathrm{B}_{2} \mathrm{O}_{3}$ has not been determined by WD-XRF, it has been determined by potenciometry

${ }^{(2)} \mathrm{Li}_{2} \mathrm{O}$ has not been determined by WD-XRF, it has been determined by FAAS

${ }^{(3)} \mathrm{LoI}$ : loss on ignition, $900{ }^{\circ} \mathrm{C}$ 
Table $3 . \mathrm{NaOH}$ waste molarity according to the storage time.

\begin{tabular}{|l|l|}
\hline Time (days) & $\mathrm{NaOH}$ molarity $(\mathrm{M})$ \\
\hline 1 & 7.2 \\
\hline 60 & 7.5 \\
\hline 365 & 8.8 \\
\hline
\end{tabular}


Table 4. Bands on the FTIR spectra of the starting materials and the activated materials.

\begin{tabular}{|c|c|c|}
\hline Peak & Wavenumber $\left(\mathrm{cm}^{-1}\right)$ & Assignment \\
\hline 1 & 3697 & $\mathrm{O}-\mathrm{H}$ stretching vibration in brucite \\
\hline 2 & 3664 & O-H stretching vibration in hydrogrossular \\
\hline 3 & 3621 & $\mathrm{O}-\mathrm{H}$ stretching vibration in muscovite \\
\hline 4 & 3437 & $\mathrm{H}-\mathrm{O}-\mathrm{H}$ stretching vibration in water \\
\hline 5 & 3431 & Muscovite band \\
\hline 6 & 3227 & Pirssonite band \\
\hline 7 & 3075 & Pirssonite band \\
\hline 8 & 2966 & Asymmetric stretching of $\mathrm{CH}_{3}$ groups \\
\hline 9 & 2919 & Asymmetric stretching of $\mathrm{CH}_{2}$ groups \\
\hline 10 & 2851 & Symmetric stretching of $\mathrm{CH}_{3}$ groups \\
\hline 11 & 2973 & Calcite band \\
\hline 12 & 2957 & Calcite band \\
\hline 13 & 2876 & Calcite band \\
\hline 14 & 2513 & Calcite band \\
\hline 15 & 1799 & Calcite band \\
\hline 16 & 1728 & Asymmetric stretching of $\mathrm{C}=\mathrm{O}$ bond \\
\hline 17 & 1641 & $\mathrm{H}-\mathrm{O}-\mathrm{H}$ bending vibration in water \\
\hline 18 & $1482-1428$ & $\begin{array}{l}\text { Asymmetric stretching vibrations of } \mathrm{CO}_{3}{ }^{2-} \text { groups (calcite, } \\
\text { dolomite, pirssonite, thermonadite) }\end{array}$ \\
\hline 19 & 1274 & Bending vibration of $\mathrm{Si}-\mathrm{C}$ bond \\
\hline 20 & 1069 & Pirssonite band \\
\hline \multirow[t]{2}{*}{21} & 1040 & $\begin{array}{l}\text { Asymmetric stretching of } \mathrm{T}-\mathrm{O} \text { bond }(\mathrm{T}=\mathrm{Si} \text { or } \mathrm{Al}) \text { in } \\
\text { anhydrous fluorescence lamp waste }\end{array}$ \\
\hline & $1017-102$ & Asymmetric stretching of $\mathrm{T}-\mathrm{O}$ bond $(\mathrm{T}=\mathrm{Si}$ or $\mathrm{Al})$ in gel \\
\hline 22 & 1028 & Muscovite band \\
\hline 23 & $875-867$ & $\begin{array}{l}\text { Out-of-plane bending of } \mathrm{CO}_{3}{ }^{2-} \text { groups (calcite, dolomite, } \\
\text { pirssonite, thermonadite) }\end{array}$ \\
\hline 24 & 796 & Hydrogrossular band \\
\hline 25 & 775 & Vibrations of $\mathrm{AlO}_{4}^{-}$tetrahedral groups \\
\hline
\end{tabular}




\begin{tabular}{|l|l|l|}
\hline 26 & 755 & Bending vibration of Si-C bond \\
\hline 27 & 728 & Calcite band \\
\hline 28 & 712 & In-of-plane bending of $\mathrm{CO}_{3}{ }^{2-}$ groups \\
\hline 29 & 655 & Pirssonite band \\
\hline 30 & 634 & Bending vibration of Si-O-Si \\
\hline 31 & 537 & Hydrogrossular band \\
\hline 32 & 534 & Muscovite band \\
\hline 33 & 475 & Muscovite band \\
\hline 34 & 456 & Bending vibration of O-Si-O \\
\hline
\end{tabular}


Table 5. Energy dispersive x-ray spectroscopy (EDS) data of the different gels in the samples.

\begin{tabular}{|c|c|c|c|}
\hline \multirow[t]{2}{*}{ Samples } & \multicolumn{3}{|l|}{ Ratio } \\
\hline & $\mathrm{Si} / \mathrm{Al}$ & $\mathrm{Na} / \mathrm{Al}$ & $\mathrm{Ca} / \mathrm{Si}$ \\
\hline 100FL & 24.90 & 20.03 & 0.09 \\
\hline $100 \mathrm{~A}$ & 1.74 & 4.34 & 3.44 \\
\hline 87.5A-12.5FL & 5.54 & 8.02 & 0.83 \\
\hline 75A-25FL & 8.24 & 12.60 & 0.51 \\
\hline $63.5 \mathrm{~A}-37.5 \mathrm{FL}$ & 16.15 & 14.31 & 0.34 \\
\hline 75A-25FL-2 & 2.18 & 4.07 & 0.79 \\
\hline
\end{tabular}


Table 6. Bulk density and mechanical bending strength of the same composition activated with different $\mathrm{NaOH}$ waste solutions.

\begin{tabular}{|l|c|c|c|}
\hline Composition & $\begin{array}{c}\text { NaOH waste solution molarity } \\
(\mathrm{M})\end{array}$ & $\begin{array}{c}\text { Bulk density } \\
\left(\mathrm{g} / \mathrm{cm}^{3}\right)\end{array}$ & $\begin{array}{c}\text { Bending strength } \\
(\mathrm{MPa})\end{array}$ \\
\hline 75A-25FL & 8.8 & $1.888 \pm 0.009$ & $6.7 \pm 0.6$ \\
\hline 75A-25FL-2 & 9.9 & $1.905 \pm 0.006$ & $6.9 \pm 0.5$ \\
\hline
\end{tabular}


Table 7. Performance classes and marking of concrete tiles for urban pavement, according to standards UNE-EN 1339:2004 and UNE 127339:2007 (UNE-EN 1339 2004; UNE 127339:2007, 2007).

\begin{tabular}{|c|c|c|}
\hline \multicolumn{2}{|c|}{ Material } & Bending strength $(\mathrm{MPa})$ \\
\cline { 1 - 2 } Class & Marking & $\geq 3.5$ \\
\hline 1 & $\mathrm{~S}$ & $\geq 4.0$ \\
\hline 2 & $\mathrm{~T}$ & $\geq 5.0$ \\
\hline 3 & $\mathrm{U}$ & \\
\hline
\end{tabular}


Table 8. Water absorption of the alkali-activated samples.

\begin{tabular}{|c|c|}
\hline Samples & Water absorption (\%) \\
\hline $100 \mathrm{FL}$ & --- \\
\hline $100 \mathrm{~A}$ & 22.5 \\
\hline $87.5 \mathrm{~A}-12.5 \mathrm{FL}$ & 24.3 \\
\hline $75 \mathrm{~A}-25 \mathrm{FL}$ & 17.5 \\
\hline $63.5 \mathrm{~A}-37.5 \mathrm{FL}$ & 22.8 \\
\hline $75 \mathrm{~A}-25 \mathrm{FL}-2$ & 15.4 \\
\hline
\end{tabular}


Table 89. Maximum values allowed for different types of landfill waste and results of the characterised sample. Leaching test according to the standard UNE-EN 12457-2, Part 2 (UNEEN 12457-2:2003, 2003).

\begin{tabular}{|c|c|c|c|c|}
\hline \multirow{2}{*}{ Component } & \multicolumn{2}{|c|}{ Maximum values allowed $\left(\mathrm{mg} \cdot \mathrm{kg}^{-1}\right)$} & \multirow{2}{*}{ 75A-25FL } \\
\cline { 2 - 4 } & Inert waste & $\begin{array}{c}\text { No dangerous } \\
\text { waste }\end{array}$ & $\begin{array}{c}\text { Dangerous } \\
\text { waste }\end{array}$ & \\
\hline $\mathrm{Ba}$ & 20 & 100 & 300 & 2.5 \\
\hline $\mathrm{Pb}$ & 0.5 & 10 & 50 & $<0.5$ \\
\hline $\mathrm{SO}_{4}{ }^{2-}$ & 1000 & 20000 & 50000 & 539 \\
\hline
\end{tabular}

